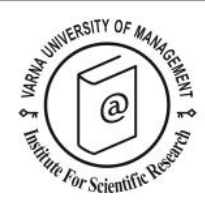

\title{
Personality and commitment as predictors of turnover intentions among Greek employees in the lodging industry
}

\author{
Kleopatra Tsaousoglou ${ }^{1^{*}}$, Dimitris Koutoulas ${ }^{2}$ and Theodoros Stavrinoudis ${ }^{3}$
}

\footnotetext{
${ }^{1}$ Department of Business Administration, University of Patras, Patras, Greece. Email: kleopatra.tsa@gmail.com

${ }^{2}$ Department of Business Administration, University of Patras, Patras, Greece

3 Department of Business Administration, University of the Aegean, Chios, Greece
}

${ }^{*}$ Corresponding author

\begin{abstract}
Employee turnover rates in the tourism industry are globally considerably high. Research on the topic has focused mostly on environmental and situational factors, with little attention given to employees' different characteristic. In the current research the effect of the Big Five personality traits and commitment on turnover intentions of lodging employees was examined. The effect of personality on commitment was examined, as well. Utilizing structural equation modelling (SEM), emotional stability and organizational commitment were found to be predictors of turnover intentional behaviour. An additional impact of occupation commitment-related variables on the prediction of organizational commitment was observed. Finally, conscientiousness was found to be the best predictor of organizational commitment. The implications of these results for future research are discussed, as well.
\end{abstract}

Keywords: Employee turnover, personality traits, hospitality human resource management, employee commitment, lodging industry

Citation: Tsaousoglou, K., Koutoulas, D. and Stavrinoudis, T. (2022). Personality and commitment as predictors of turnover intentions among Greek employees in the lodging industry. European Journal of Tourism Research 31, 3111. 


\section{Introduction}

Tourism is considered the world's fastest growing industry and it is among the highest earners of foreign currency (Boella \& Goss-Turner, 2019). In 2019, the travel and tourism sector grew at a rate of 3.5\% (World Travel \& Tourism Council [WTTC], 2020). Tourism depends a lot on the human factor, as it is a labour-intensive industry (Durbarry \& Sinclair, 2003; Boella \& Goss-Turner, 2019; González-Santacruz, Sánchez-Cañizares, \& López-Guzmán, 2014). The travel and tourism sector accounts for 10.3\% of global GDP and 330 million jobs, which can be translated in 10.4\% of total employment in 2019. Globally $10 \%$ of the employment is provided by the tourism industry (WTTC, 2020). However, the hospitality industry has a reputation for high levels of labour turnover worldwide, ranging from $60 \%$ to $300 \%$ (Boella \& Goss-Turner, 2019; Riley, 2018; Kim, 2014; Tesone, 2008; Hinkin \& Tracey, 2000; Nadiri \& Tanova, 2010; Park \& Min, 2020), holding one of the highest position in employee turnover among private-sector industries (US Department of Labor, 2015).

Turnover in hospitality affects profitability, competitive advantage, quality and level of service provided to customers, as well as customers' engagement and brand's image (Kang, Busser, \& Choi, 2018; Dusek, Ruppel, Yurova, \& Clarke, 2014). When employee turnover occurs, the company must spend time and resources to fill the vacancy. This results to in both direct and indirect costs, that can hardly be measured in detail (Karsan, 2007; Faldetta, Fasone, \& Provenzano, 2013) and often exceed 100\% of the annual salary for the vacated positions (Bryant \& Allen, 2013). Separation, replacement, and training costs can reach 1.5 to 2.5 times the annual salary for each employee that leaves the organization (Rust, Stewart, Miller \& Pielack, 1996, p. 63).

High employee turnover rates are an important issue for the Greek lodging industry, as well (Chalkiti \& Sigala, 2010). The lodging sector represents $45 \%$ of Greece's total tourism income (Institute SETE [INSETE], 2015). The tourism sector represents $20.8 \%$ (around 23 billion) of Greek GDP and $21.7 \%$ of all employment (around 846,200 jobs) in Greece (WTTC, 2020). Despite the crucial impact of tourism on the Greek economy, the research focus on employee turnover issues is surprisingly low (Chalkiti \& Sigala, 2010), and no official records regarding employee turnover in the Greek hospitality industry are available (Sigala, 2006).

There is thorough literature on employee turnover, but researchers and academics have been focused mostly on environmental and situational factors (Zimmerman, 2008). However, according to Zimmerman (2008), instead of trying to retain high-performing employees after they are hired, it might be worth taking into consideration their propensity to quit, regardless of the working conditions or circumstances.

According to Mercer (1988, p. 38) "the most direct, cost-effective way to reduce turnover is probably to use valid, reliable employment selection tests that pinpoint which applicant fits the model of the longterm, effective employee". Cho, Johanson and Guchait (2009) in their study of management practices on hospitality firms (hotel and restaurants with more than 100 employees) in the US, revealed that even though pre-employment tests are rarely used in the industry, when they do so they contribute to lower the turnover rates of non-managerial employees. This implies that using pre-employment tests can indeed decrease turnover rates. However, tourism and especially the hospitality sector has built a reputation of poor and opportunist staff selection methods lacking even widely established practices (Anastassova \& Purcell, 1995; Hoque, 1999; McGunnigle \& Jameson, 2000; Armstrong \& Taylor, 2014).

Employees joining an organization already have some previous work experience but also feelings and attitudes towards responsibilities, tasks and the working conditions under which they are asked to work 
(Mullins \& Dossor, 2013). Thus, people join a business with some dispositions that are unrelated to the new work environment and already have specific characteristics affecting their behavior, most notably perceptions, values, personality characteristics and attitudes. These characteristics are quite difficult to be changed when the employees enter an organization and consequently not much can be done about them, even though their impact on behavior is quite important (Langton \& Robbins, 2007). Thus, hiring the candidate with the appropriate characteristics and dispositions seems very important.

Concerning personality, research indicates that it is an important determinant of employee turnover intentions and actual turnover behaviour (Barrick \& Mount, 1991; Salgado, 2002; Zimmermann, 2008). Park and Min (2020) in their meta-analysis identified 100 antecedents of turnover intention in the hospitality research, among which 35 have been considered as major and were classified in nine categories. According to their meta-analysis, the nine major antecedents of turnover intention in hospitality are work attitudes, job strains, human resource management practices, role stressors, supervisors' behaviours, employee performance, organisational contextual factors, emotional labour, and individuals' attributes. Interestingly, in the category of individuals attributes only three studies are referred (Shoda, Mischel, \& Wright, 1993; Skarlicki, Folger, \& Tesluk, 1999; Karatepe, Arasli, \& Khan, 2007) and none of them examines personality in terms of turnover intentions.

It is clear, therefore, that in the context of hospitality, little attention has been paid to personality as an antecedent of turnover intention. In those limited studies, personality has been examined either as a set or with focusing only on one or two traits (Kozako, Safin \& Rahim, 2013; Ariyabuddhiphongs \& Marican, 2015). However, this evidence may be encouraging as it suggests that turnover propensities can be identified even in the pre-entry stage. This implies that turnover might be controlled also during selection (Barrick \& Zimmerman, 2005; Griffeth, Hom, \& Gaertner, 200o) and support managerial decisions at an organizational level, as well. Therefore, the first purpose of this research is to examine if personality affects turnover behaviour in the hospitality context.

In the same vein, the work attitude of commitment is considered as a valuable predictor of employee turnover (Griffeth \& Hom, 1995; Yang, 2008; Tziner, Waismal-Manor, Vardi \& Brodman, 2008). Employee commitment is still a central topic of interest of many studies in organisational psychology, mainly because of is its predictive features to different work outcomes including withdrawal behaviours such as turnover (Vance, Jaros, Becker, \& McKay, 2020). The negative relationship between commitment and turnover has been widely confirmed in the hospitality context (for instance, Carbery, Garavan, O'Brien, \& McDonnell, 2003; Cho et al., 2009; Zopiatis, Constanti, \& Theocharous, 2014; Park \& Min, 2020; Lee, Huang, \& Zhao, 2012) in different countries.

At the same time, commitment has only recently been associated with personality (Erdheim, Wang, \& Zickar, 2006; Zettler, Friedrich \& Hilbig, 2011; Choi, Oh, \& Colbert, 2015) and research on this topic is scarce. The only available research trying to connect personality with organizational commitment in the hospitality context is Silva's (2006). These limited results may imply that commitment can be evaluated not only based on environmental and situational factors but dispositional factors like personality traits should be considered, too.

Perceptions of a workplace may be affected by idiosyncratic traits (Scarr, 1996) and previous work experience (Mullins \& Dossor, 2013; Langton \& Robbins, 2007). A connection of personality with commitment and commitment with turnover may provide managers and academics with valuable information regarding personality, turnover models, and work attitudes in the hospitality context. 
Therefore, the second purpose of the study is to examine the role of personality on commitment and in turn the role of commitment on turnover intention in the lodging context.

After reviewing the related literature through Web of Science database to the authors' knowledge, no research has been found in the accommodation sector focusing on exploring employees' turnover intentional behaviour on a dispositional base. Should a dispositional feature of turnover and commitment be confirmed, then evaluating personality during the selection procedure can become valuable for managers, who will be supported to hire people that have less vocation to express turnover behaviour. Additionally, the results of the current study can contribute to the growing body of literature regarding personality, commitment, and turnover intentions of employees in the hospitality context, as research on the topic is very limited.

\section{Literature review and hypothesis development}

\section{Personality and turnover}

There are different models examining personality. The Five Factor Model (FFM) is one of the leading models that evaluates personality and has been widely examined in numerous countries and languages (Armstrong \& Taylor, 2014; Tews, Stafford, \& Tracey, 2011; Wu \& Mursid, 2019). In the work context, the Five Factor Model has been used in different studies to examine the predictive validity of personality at work (Barrick, Mount, \& Judge, 2001). However, according to Salgado (2002), little systematic research has been focused on investigating whether counterproductive behaviours such as turnover could be predicted by estimating the Big Five personality traits. Extraversion, emotional stability, agreeableness, conscientiousness, and intellect are the elements of the Big Five Factor Model, that can explain personality differences among individuals (Costa \& McCrae, 1992). These traits are very important for the tourism industry, as well (Kusluvan, 2010), but their connection to turnover has been limited (Ariyabuddhiphongs \& Marican, 2015).

Extraversion reflects individual traits such as being sociable, gregarious, assertive, talkative, and active (Kim, Shin, \& Umbreit, 2007; Tews, Stafford, \& Zhu, 2009). It also refers to the extent to which people are warm, friendly, and dominant in social situations (Zhao, Seibert, \& Lumpkin, 2010). As extraversion is characterised by positive feelings and experiences, it is considered a positive affect (Watson \& Clark, 1997). Positive emotions and better networking as results of extraversion traits imply that people with high extraversion will be less likely to quit (Zimmerman, 2008; Wanberg, Kanfer, \& Banas, 200o). Given that the lodging industry requires advanced social skills (Kim et al., 2007), and positivity is foregrounded in hospitality employees (Gatling, Kang, \& Kim, 2016), extraversion is expected to play an important role for employees and be negatively related with turnover intentions.

Emotional Stability refers to people that are usually calm, relaxed, generally free from worry (Tews et al., 2009), even-tempered, able to face stressful situations without becoming upset (Rothmann \& Coetzer, 2003), coping easily with negative emotions (Michel, Clark, \& Jaramillo, 2011; Choi \& Lee, 2014), and hardy (Zhao et al., 2010). People with a lack of emotional stability (i.e., neuroticism) are sensitive to negative feedback and easily become discouraged by small failures, feel easily worried, hopeless, or panicked when they face difficult situations (Zhao et al., 2010). Dunn, Mount, Barrick, \& Ones (1995) found that emotional stability is the second most important characteristic that affects the fit to work of candidates. Given that hospitality is a very stressful and demanding sector, where the needs of clients should be fulfilled around the clock daily (Kim et al., 2007) positively, emotional stability is expected to play an important role in the lodging industry and have a strong negative correlation with organisation turnover intentions. 
Agreeableness is a dimension that evaluates an individual's attitude and behaviour toward people (Zhao et al., 2010). Agreeableness refers to the warmth, friendliness, kindness, empathy in social interactions of individuals (Kim et al., 2007). People high in agreeableness tend to be altruistic, generous, trusting, and cooperative (Tews et al., 2009). Additionally, people high in agreeableness prefer social occupations due to the frequent interpersonal interactions (Zhao et al., 2010). On the other hand, individuals low in agreeableness seem to quit their job in an unexpected manner (Zimmerman, 2008), and are ignorant of workplace rules displaying deviant behaviours as they disagree easily with others (Durak \& Saritepeci, 2019). Agreeableness is considered a valuable predictor in jobs that require teamwork and in the customer service sector (Rothmann \& Coetzer, 2003). Thus, individuals high in agreeableness are less likely to quit as they tend to create better interpersonal relationships in the workplace which may help them having positive working experiences (Zimmerman, 2008). According to Kim et al. (2007), though, research results on this dimension vary regarding the relationship with work performance. Hotel employees high in agreeableness seem to be the best to easily identify guests' needs in accommodation and in this way strong positive guest relationships can be created, ensuring repeat guests and more profitability. Hiring employees high in agreeableness in the lodging industry can be an asset for organisations, as guests pay much attention to personalised services (Kim et al., 2007). Thus, a strong negative relationship is reasonable to be expected between agreeableness and turnover intentions.

Conscientiousness reflects an individual's dependability and volition. Dependability refers to how careful, organised, thorough, and responsible is someone and volition refers to how hardworking, persevering and achievement-oriented is someone (Kim et al., 2007). Individuals high in conscientiousness are trustworthy, committed (Durak \& Saritepeci, 2019), punctual, and well-organised (Tews et al., 2009). However, there is a negative side of high conscientiousness, as it may lead individuals to annoying fastidiousness, compulsive neatness, and workaholic behaviour (Rothmann \& Coetzer, 2003). A strong relationship between job performance and conscientiousness was found in various studies (Rothmann \& Coetzer, 2003; Kim et al., 2007) and is reported to be the most important predictor among the five dimensions of FFM in the workplace. Given that the hospitality industry is a very demanding sector where clients' needs should be fulfilled all day long in a professional and dependable manner, conscientiousness is expected to play an important negative role on turnover intentions of employees.

Intellect represents how imaginative, cultured, curious, broad-minded, artistically sensitive (Barrick \& Mount, 1991; Durak \& Saritepeci, 2019), and flexible (Michel, Clark, \& Jaramillo, 2011) people are. These people tend to be original, unconventional, independent (Tews et al., 2009) and they have a breadth of interests (Fang et al., 2015). In the workplace people high in intellect face difficulties as opportunities to develop themselves and not as cases of negative emotions (Durak \& Saritepeci, 2019). Research on this dimension reveals contradictory results regarding its relationship with job performance, something that maybe has to do with the different requirements of each job (Rothmann \& Coetzer, 2003). Regarding the hospitality industry, it is expected that intellect will be positively correlated with turnover intentions as this industry needs dedicating and obeying people to offer the "perfect" hospitality product to the "demanding" consumers of tourism products.

Based on these approaches, the following hypotheses are formulated:

Hypothesis 1a. There is a negative relationship between four of the dimensions of the Big Five Factor Model (extraversion, agreeableness, conscientiousness, and emotional stability) and intention to leave organisation.

Hypothesis $\mathbf{1 b}$. There is a positive relationship between the dimension of Intellect/Imagination of the Big Five Factor Model and intention to leave organisation. 


\section{Commitment and turnover}

Within highly competitive environments, organisations nowadays acknowledge the crucial need for committed staff (Albrecht, Bakker, Gruman, Macey, \& Saks, 2015). Meyer (2009) defined commitment as an "internal force that binds an individual to a target (social or non-social) and/or to a course of action or relevance to that target" (p. 39).

There are two main groups of foci: the internal that includes commitment to organizational goals or an organization's members and external foci that include commitment to factors that are outside of the organization such as occupation, customers and suppliers (Siders, George, \& Dharwadkar, 2001). The most frequently studied topic in the commitment literature is organizational commitment (Vance et al., 2020) and, therefore, empirical evidence regarding other foci like occupational commitment, is scarce.

There is rich literature suggesting that there is a strong negative relationship between an employee's intention to turnover and organisational commitment in the hospitality context (Park \& Min, 2020; Yang, 2008; Cho et al., 2009). No data about the Greek hospitality industry have been found.

Occupational commitment was also found to be correlated with organizational turnover in a way that people high in occupational commitment are less likely to quit from the organisation (Blau \& Lunz, 1998; Lee, Carswell, \& Allen, 200o; Yousaf, Sanders \& Abbas, 2015; Chang, 1999). According to Morrow (1983), occupational commitment is a more stable type of work commitment than organisational commitment. Occupational commitment is also perceived to have a direct relation to the individuals' personality and not always influenced by the contextual organisation (Freund \& Carmeli, 2003). People who feel committed to their occupation are approaching organisation as a place that allows them to apply their occupational skills (McAulay, Zeitz, \& Blau, 2006). Consequently, they experience higher organizational commitment, as a bidirectional beneficial relationship is established.

Lee et al. (2000) claimed that occupational commitment, in comparison with organisational commitment, is a stronger predictor of organisational turnover intentions. Therefore, they proposed that measuring occupational and organisational commitment simultaneously may improve our ability to predict organisational turnover. Similar results were found by other studies (Tsoumbris \& Xenikou, 2010; Yousaf et al., 2015). Yousaf et al. (2015) found that people who are committed to their organisation express low intention to leave and this relationship is getting stronger for those being at the same time highly occupationally committed.

In their meta-analysis, Lee et al. (200o) also found that the relationship between occupational commitment and intention to leave the organisation is fully mediated by intention to leave the occupation. A full mediating role of intention to leave the occupation was found by Chang, Chi and Miao (2007), as well. This means that the total effect of occupational commitment on intention to leave the organisation is explained through intention to leave the occupation. Career stage was also found to moderate the relationship between organisational commitment and intention to leave organisation the organisation (Cohen, 1993). This highlights the importance of measuring the occupational commitment-related variables as part of turnover models, as these variables are highly neglected in the literature (Lee et al., 2000).

However, within the context of the hospitality sector, there is no evidence on the effect of occupational commitment variables on turnover. Therefore, it seems valuable to examine the role of occupationalrelated variables on organisational turnover intentions (i.e. occupational commitment and intention to 
leave the occupation) concurrently with organisational commitment. In this way a better prediction of turnover intentions may be achieved.

The present study adopts the Three-Component Model (TCM) of Allen and Meyer (1991). This model is the leading model to the conceptualisation and measurement of employee commitment (Vance et al., 2020). Although TCM has been criticised by various researchers, it remains the leading model for commitment, which has been widely examined in different settings during the last years, and it has been tested thoroughly, theoretically, and methodologically (Allen, 2016). This model has been extended in different work-related foci beyond the organisation. Besides, meta-analytic evidence suggests that there is negative correlation between the TCM dimensions and turnover intention (Allen, 2016).

Among the three components of commitment, only affective commitment - both in organisation and in occupation - was measured in this study. There is evidence that affective commitment has the strongest and most favourable relationship with organisation-relevant and employee-relevant outcomes. Therefore, is supposed to be the most beneficial type of commitment for organisations (Meyer \& Allen, 1997). Affective organizational commitment "refers to the employee's emotional attachment to identification with and involvement in the organization" (Meyer \& Allen, 1991, p. 67). In addition, affective organisational commitment has the strongest negative correlation with turnover (Meyer, Stanley, Herscovitch, \& Topolnytsky, 2002; Vandenberghe, Bentein, \& Panaccio, 2014; Joung, Goh, Huffman, Yuan, \& Surles, 2015) and is the dominant measure in commitment studies (Meyer et al., 2002).

Accordingly, affective occupational commitment refers to an employee's emotional identification with his/her occupation and work goals (Lee et al., 2000; Vandenberg \& Scarpello, 1994; Yousaf, Sanders, \& Shipton, 2013). Thus, employees that are affectively committed to their occupation feel positive emotions about their occupation.

Several studies conducted since 2008 have shown the existence of high turnover rates that occur in the tourism industry (Boella \& Goss-Turner, 2019; Riley, 2018; Park \& Min, 2020; Chalkiti \& Sigala, 2010). Additional studies covering the same period have also shown the predictive features of commitment variables in terms of organisational turnover intention (Cho et al., 2009; Zopiatis et al., 2014; Park \& Min, 2020). Thus, it seems crucial to investigate the role of commitment on intentional turnover behaviour within the lodging industry and more specifically in Greece. This will provide further implications for academics and especially for hospitality managers, who can use this approach in their hiring process.

Based on these approaches, the following hypotheses have been formed.

Hypothesis 2a: There is a negative relationship between affective organisational commitment and intention to leave the organisation.

Hypothesis $\mathbf{2 b}$ : There is a negative relationship between affective occupational commitment and intention to leave the organisation.

Hypothesis 2c: The relation between occupational commitment and intention to leave the organisation is mediated by intention to leave the occupation.

Hypothesis 2d: The relationship between organisational commitment and intention to leave the organisation is getting stronger for higher levels of occupational commitment. 
Commitment and personality

Although personality and affective commitment of employees are connected with turnover, there has been limited research on investigating the dispositional basis of organisational commitment (Erdheim et al., 2006; Zettler et al., 2011; Spagnoli \& Caetano, 2012; Choi et al., 2015; Guay et al., 2016). Empirical research had focused mostly on situational and experiential antecedents regarding organisational commitment.

The person-centred approach regarding commitment only lately began to draw the attention of researchers (Bergman \& Jean, 2016, Meyer, Stanley, \& Vandenberg, 2013). Choi et al. (2015) through their meta-analysis stated that, apart from work environments, organisational commitment is also influenced by personality traits of individuals. This might be explained because perceptions of work environments are affected by individuals' idiosyncratic traits. However, the meta-analytic results of Choi et al. (2015) were based on a small number of studies due to a lack of literature on the topic and, therefore, further research on the topic is needed.

Some additional studies using different frameworks confirmed the utility of dispositions in predicting organisational commitment, even when an individual's traits are evaluated before any work experience take place (Rubenstein, Zhang, Ma, Morrison, \& Jorgensen, 2019; Judge, Higgins, Thoresen, \& Barrick, 1999; Indarti, Fernandes, \& Hakim, 2017). However, in the context of hospitality employees, only Silva (2006) analysed the connection between personality and commitment. This study has limited implications, though, as only correlation between personality and organizational commitment was examined and, therefore, no information on the way that personality affects commitment was provided. In addition, commitment was treated as a singular trait and not according to Meyer's Model classification of three distinct components.

The main feature of extraversion is positive emotionality, which encourages people to perceive their work environments more positively and makes them recall more easily positive information about their organisation (Watson \& Clark, 1997). These people are more motivated to stay in their organisations (Meyer \& Allen, 1991). Due to the social aspect of extraversion, people who are high in this dimension can more easily create social relationships in their work environment, which consequently can make them feel more connected with the organisation (Costa \& McCrae, 1992; Michel et al., 2011; Choi \& Lee, 2014). Given the fact that social skills are important in hospitality, it is reasonable to expect that extraversion will be positively correlated with affective organisational commitment in the lodging industry. This positive connection between the two variables has already been examined and confirmed by Erdheim et al. (2006), Zettler et al. (2011), Spagnoli and Caetano (2012), as well as Choi et al. (2015). The interpersonal components of agreeableness help individuals to create a pleasant work environment and strengthen the emotional attachment to the organisation (Ilies, Fulmer, Spitzmuller, \& Johnson, 2009). Individuals high in agreeableness usually develop positive relations with colleagues and integrate easily into new environments (Michel et al., 2011; Choi \& Lee, 2014). In addition, people high in agreeableness can easily identify themselves with the organisation and they can be more patient with unfair experiences within the workplace (Choi et al., 2015). A positive correlation between affective occupational commitment and agreeableness has been observed by Choi et al. (2015), whereas a negative correlation has been observed by Zettler et al. (2011). Considering that affective organisational commitment represents a positive emotional attachment to organisation, and that coping with demanding customers' needs is inextricably linked with the hospitality industry, it is reasonable to expect a positive relationship between agreeableness and affective organisational commitment. 
Conscientiousness makes employees feel responsible and have an obligation to stay with the establishment (Michel et al., 2011; Choi \& Lee, 2014). A strong relationship between conscientiousness and job involvement has been observed (Rothmann \& Coetzer, 2003; Kim et al., 2007). Additionally, people high in conscientiousness are more likely to become affectively committed to the organisation (Farrukh, Ying, \& Mansori, 2017). A positive correlation between conscientiousness and affective organisational commitment has been confirmed also by Choi et al. (2015), Erdheim et al. (2006) and Farrukh et al. (2017). Taking into consideration that in the hospitality industry responsibility and professionalism play an important role in fulfilling guest expectations, it is reasonable to expect a positive relationship between conscientiousness and affective organisational commitment.

People high in emotional stability present a more stable personality and tend to focus on the positive side of the situations they face within their work environment (Durak \& Saritepeci, 2019). These people easily create positive relationships, too. As affective organisational commitment is referred to as a positive attachment to the organisation, a positive correlation can be expected. Previous researchers on the topic have confirmed this positive correlation (Erdheim et al., 2006; Choi et al., 2015). Given that creating positive relationships with customers is important in the hospitality sector, we can assume that individuals high in emotional stability are more likely to be affectively committed to their organisation, as well.

People high in the dimension of intellect are open to new experiences and always consider other job opportunities (Michel et al., 2011; Choi \& Lee, 2014). Individuals high in intellect tend to unconventionality and doubting authority (Durak \& Saritepeci, 2019). Intellectual individuals are primarily interested in new experiences and independence and, consequently, feel less attached to an organisation and its values. Previous evidence of Choi et al. (2015) supported a positive correlation of intellect with affective commitment, whereas Spagnoli and Caetano (2012) found a negative correlation in their study. Considering that hospitality requires dedication and stability, we assume that people high in intellect will be not affectively committed to the organisation.

Based on the above discussion, the following hypotheses are formed:

Hypothesis 3a: There is a positive relationship between the four dimensions of the Big Five Factor Model (extraversion, agreeableness, conscientiousness, and emotional stability) and affective organisational commitment.

Hypothesis $3 \boldsymbol{b}$ : There is a negative relationship between the dimension of intellect/imagination and affective organisational commitment.

Table 1 summarises previous studies conducted in regard to the aforementioned relationships that have focused on the hospitality sector.

\section{Materials and methods}

Data collection and analyses

The detailed review of relevant literature enabled the development of a self-administered quantitative questionnaire with the aim of addressing the aforementioned hypotheses. The population for this study comprised Greek accommodation-sector employees. Online survey distribution was selected due to the lack of a reliable point of reference about the population of Greek hospitality workers. At the same time this method offers easy accessibility, has low cost, is speedy, the participation is voluntary and there is a lack of time limitation (Schonlau, Ronald, \& Elliott, 2002; Riva, Teruzzi, \& Anolli, 2003; Tasci \& Knutson, 2003). Thus, non-probability sampling was chosen as the preferred method of finding 
respondents to the online survey for this research. More specifically, the currents' research target population was employees in different accommodation businesses in different locations in Greece. Participants came from different department of accommodation businesses such as sales and reservations, food service, kitchen, housekeeping, management, accounting etc. Finally, participants consisted of frontline workers, supervisors and managers. It is important to mention that no particular subgroup among the target population has been excluded. Therefore, the resulting sample of the present survey should be considered reliable enough.

Table 1. Overview of related studies connecting personality, commitment and turnover in the hospitality sector

\begin{tabular}{|c|c|c|}
\hline Subject of analysis & Study & Key results \\
\hline Personality-turnover intentions & $\begin{array}{l}\text { Big Five personality traits and } \\
\text { turnover intention among Thai } \\
\text { hotel employees } \\
\text { (Ariyabuddhiphongs \& Marican, } \\
\text { 2015) }\end{array}$ & $\begin{array}{l}\text { Negative relationship between } \\
\text { personality (measures as set) and } \\
\text { turnover intentions among hotel } \\
\text { employees in Thailand }\end{array}$ \\
\hline \multirow[t]{5}{*}{ Commitment-turnover intentions } & $\begin{array}{l}\text { Predicting hotel managers' } \\
\text { turnover cognitions (Carbery et al., } \\
\text { 2003) }\end{array}$ & $\begin{array}{l}\text { Affective organisational } \\
\text { commitment negatively predicts } \\
\text { hotel managers' intention to leave } \\
\text { organisation in Ireland }\end{array}$ \\
\hline & $\begin{array}{l}\text { Employees intent to leave: A } \\
\text { comparison of determinants of } \\
\text { intent to leave versus intent to stay } \\
\text { (Cho et al., 2009) }\end{array}$ & $\begin{array}{l}\text { Affective organisational } \\
\text { commitment negatively predicts } \\
\text { turnover intentions among } \\
\text { employees in restaurant and hotels } \\
\text { in U.S. }\end{array}$ \\
\hline & $\begin{array}{l}\text { A study on factors affecting } \\
\text { turnover intention of hotel } \\
\text { employees (Lee et al., 2012) }\end{array}$ & $\begin{array}{l}\text { Organisational commitment } \\
\text { negatively predicts turnover } \\
\text { intentions among hotel employees } \\
\text { in Taiwan. }\end{array}$ \\
\hline & $\begin{array}{l}\text { Job involvement, commitment, } \\
\text { satisfaction and turnover (Zopiatis } \\
\text { et al., 2014) }\end{array}$ & $\begin{array}{l}\text { Affective organizational } \\
\text { commitment negatively predicts } \\
\text { turnover intentions among hotel } \\
\text { employees in Cyprus }\end{array}$ \\
\hline & $\begin{array}{l}\text { Turnover intention in the } \\
\text { hospitality industry: A meta- } \\
\text { analysis (Park \& Min, 2020) }\end{array}$ & $\begin{array}{l}\text { Organisational commitment is the } \\
\text { strongest negative antecedent of } \\
\text { turnover intention in hospitality }\end{array}$ \\
\hline Personality and commitment & $\begin{array}{l}\text { Effects of disposition on hospitality } \\
\text { employee job satisfaction (Silva, } \\
\text { 2006) }\end{array}$ & $\begin{array}{l}\text { Positive relationship between } \\
\text { organisational commitment and } \\
\text { the personality traits of } \\
\text { extraversion, emotional stability, } \\
\text { conscientiousness. } \\
\text { Conscientiousness had the } \\
\text { strongest correlation with } \\
\text { organisational commitment }\end{array}$ \\
\hline
\end{tabular}

For the pilot study, the questionnaire was sent to 20 employees of 4 different hotels by using Facebook Messenger. After making minor changes to the questionnaire, the online survey was posted on Greek Facebook group pages for hospitality workers. The online questionnaire was available for seven weeks between November 2019 and January 2020. The response rate cannot be calculated as there is no data available about the number of post views. The questionnaire took about 15 minutes to complete. An introductory text explained the purpose of the study and assured respondents that their answers would 
be anonymous and confidential and to be used only for research purposes. Data collection was in accordance with the guidelines of the Helsinki's Declaration for ethics in medical research (World Medical Association, 2001). The Google Forms tool was used for data collection.

A total of 800 responses were received, 665 of which were included in the study, resulting in a final effective response rate of around 83\%. Of the 800 responses, 135 responses were excluded due to respondents' failure to correctly answer the control questions that were included in the questionnaire to avoid careless responses. The final sample size of 665 participants is considered adequate, taking into considerations the SEM and PLS requirements, which will be analysed in the following section (Roscoe, 1975; Siddiqui, 2013; Anthoine, Moret, Regnault, Sébille, \& Hardouin, 2014; Hair, Sarstedt, et al., 2017).

\section{Measurement}

The questionnaire consists of five sections and aims to cover the research questions. At the beginning of each section, detailed instructions were provided about properly responding to the questions. Participants were also asked to respond in honestly and always in relation to how they feel, think and react in the workplace.

The first section contains 16 closed-type questions regarding participants' working status, position, current working conditions, working experience in the tourism industry and more specifically in the accommodation sector, and the duration of the longest period they have worked for the same employer. The second section contains the 50-item version of Goldberg's (1999) International Personality Item Pool (IPIP) that evaluates the personality dimensions of the well-known Big Five Factor Model. The 50item version of IPIP is available in the Greek language and its validity has already been tested among the Greek population (Ypofanti et al., 2015). Besides, IPIP is cost-free, anyone can have access to all of its items, scoring keys are available on the internet, its items can be translated into other languages, and can be administered worldwide without any need of permission of anyone (Goldberg, et al., 2006). Respondents were asked to rate this instrument's statements on a five-point scale ( $1=$ Very inaccurate, 2=Moderately Inaccurate, 3=Neither Inaccurate nor Accurate, 4=Moderately Accurate, 5=Very accurate). Each of the five dimensions was measured by 10 items. After reversing some questions (according to keys), the final score of each participant in each of five dimensions is measured by the sum of 10 items answers. The closest the participants' final score is to value '50' ('10'), the higher (less) is characterised by the evaluated personality trait.

In the third section affective organisational and occupational commitment were measured using the affective commitment scale developed by Meyer and Allen (1991). Affective occupational commitment scale consists of 6 items. This scale was scored by means of a seven-point Likert-type scale ranging from 1 (strongly disagree) to 7 (strongly agree). The affective organisational commitment scale consists of 6 items too, also scored by means of a seven-point Likert-type scale ranging from 1 (strongly disagree) to 7 (strongly agree). After reversing some questions, the final scale score is measured by the average score of related items answers. The closest the participants' final score is to value ' 7 ' (' 1 '), the higher (less) is characterised by the evaluated personality trait.

Actual turnover is challenging to measure (Lingard, 2003), because once employees leave, either the employees are difficult to find or their response rates to surveys are usually low (Johnsrud \& Rosser, 2002). However, there is literature supporting that turnover intention is the best immediate predictor of actual turnover behaviour (Bluedorn, 1982; Balogun \& Agesin, 2014; Zopiatis et al., 2014). Thus, in the questionnaire's fourth section, intention to leave the organisation and the occupation was measured by providing six items (three items for each variable). Turnover intentions have been measured reliably by 
tools of three to five items in many studies (Jang \& George, 2012; Zopiatis et al., 2014). More specifically, to evaluate participants' intention to leave the organisation, they were asked how frequently they thought about getting out of the occupation, how likely it was that they would explore other career opportunities, and how likely it was that they would leave their present occupation within the next year. Respectively, intention to leave the organisation was evaluated by asking participants how frequently they thought about leaving their current employer, how likely it was that they would search for a job in another organisation and how likely it was that they would actually leave the organisation within the next year. Responses were made on appropriately labelled 7-point scales and were averaged across items to yield composite intention scores according to the instructions of Meyer, Allen, and Smith (1993). The closest the final turnover score is to value ' 7 ' (' 1 '), the more this participant is characterised by high (low) intention to leave the organisation or occupation. The same back-translation method was used as with organisational and occupational commitment for identifying the intention to leave the organisation and occupation, as well.

Finally, the fifth section contains questions about demographic information including age, gender, marital and educational status.

\section{Results}

Analysis and results

The SmartPLS 3 software (Ringle, Wende, \& Becker, 2015) was used for analysis. Partial Least SquaresStructural Equations Modeling (PLS-SEM) is a widely accepted technique that is preferred when theory is underdeveloped, and prediction and explanation of endogenous constructs is the focus of the research. In addition, PLS does not require distributions assumptions as it is nonparametric and is more flexible in handling more complicated models. (Hair et al., 2014; Hair, et al., 2016; Matthews, Hair \& Matthews, 2018; Hair, Sarstedt, et al., 2017). Although one of PLS advantages is that is working properly in small samples sizes $(\mathrm{N}<100)$, it is effective in analysing data of large sample too (Hair, Hollingsworth, et al., 2017). Thus, as this research focuses on predictions, data is non-parametric and the sample is quite large ( $\mathrm{N}=665)$, PLS-SEM is the appropriate choice for analysis.

\section{Descriptive statistics and demographics}

A total of 665 respondents with a mean age of 35.4 years (interquartile range [IQR]) were finally included in the study. Two hundred and forty-four were men (36.7\%) and $421(63.3 \%)$ were women. Among them, $342(51.4 \%), 268(40.3 \%), 51$ (7.7\%), and 4 (0.6\%) were unmarried, married, divorced, and widowed, respectively. More than half of them (373 respondents; $56.1 \%$ ) have completed tourism studies. The majority worked at 4 to 5 -star hotels (531 respondents; 79.8\%) and 1 to 3 -star hotels (91; 13.7\%). The majority $(42.7 \%)$ worked in large hotels with a capacity of more than 200 beds (Table 2 ). The departments with the most common respondents were "Sales and Reservations" (222 respondents; 33.4\%), "Food Service" (130, 19.5\%), and "Kitchen” (119, 17.9\%).

The average employment within the tourist industry was 7 seasons (IQR 4-12 seasons), whereas particularly in the accommodation sector was 6 seasons (IQR 3-11 seasons). Respondents' average longest period working for the same lodging employer was 3 years (IQR 2-6 years). Descriptive statistics of measurement scales including mean and standard deviation are shown in Table 3. 
Table 2. Demographics.

\begin{tabular}{|c|c|c|c|c|c|}
\hline Gender & $n$ & $\%$ & Tourism Education & $n$ & $\%$ \\
\hline Male & 244 & 36.7 & Yes & 375 & 56.4 \\
\hline Female & 421 & $63 \cdot 3$ & No & 290 & 43.6 \\
\hline Age & & & Work location & & \\
\hline $18-30$ & 258 & 38.8 & Greek Islands & 415 & 62.4 \\
\hline $31-40$ & 221 & 33.2 & Towns & 134 & 20.2 \\
\hline $41-50$ & 124 & 18.6 & Athens/Thessaloniki & 104 & 15.6 \\
\hline Over 50 & 62 & 9.4 & Undefined & 12 & 1.8 \\
\hline Marital Status & & & Working exclusively & sm & \\
\hline Single & 342 & 51.4 & Yes & 529 & 79.5 \\
\hline Married & 268 & 40.3 & No & 136 & 20.5 \\
\hline Divorced & 51 & $7 \cdot 7$ & & & \\
\hline Widowed & 4 & 0.6 & & & \\
\hline
\end{tabular}

Table 3. Descriptive statistics.

\begin{tabular}{|c|c|c|c|c|}
\hline Variables & Items & Description & Mean & SD \\
\hline \multirow[t]{11}{*}{ Extraversion } & Ex1 & Am the life of the party & 3.184 & 1.294 \\
\hline & Ex2 & Don't talk a lot & 3.421 & 1.337 \\
\hline & $\mathrm{Ex}_{3}$ & Feel comfortable around people & 4.011 & 1.087 \\
\hline & Ex4 & Keep in the background & 3.170 & 1.304 \\
\hline & Ex5 & Start conversations & 3.844 & 1.155 \\
\hline & Ex6 & Have little to say & 3.881 & 1.151 \\
\hline & Ex7 & Talk to a lot of different people at parties & 3.266 & 1.432 \\
\hline & Ex8 & Don't like to draw attention to myself & 2.615 & 1.312 \\
\hline & Exy & Don't mind being the centre of attention & 2.985 & 1.374 \\
\hline & Ex10 & Am quiet around strangers & 2.450 & 1.273 \\
\hline & Construct & & 33.740 & 7.953 \\
\hline \multirow[t]{11}{*}{ Agreeableness } & Agree1 & Feel little concern for others & 4.077 & 1.259 \\
\hline & Agree2 & Am interested in people & $4 \cdot 546$ & 0.759 \\
\hline & Agree3 & Insult people & $4 \cdot 710$ & 0.676 \\
\hline & Agree 4 & Sympathize with others' feelings & 4.141 & 0.975 \\
\hline & Agree 5 & Am not interested in other people's problems & $4 \cdot 381$ & 0.985 \\
\hline & Agree6 & Have a soft heart & 3.959 & 1.178 \\
\hline & Agree7 & Am not really interested in others & $4 \cdot 544$ & 0.831 \\
\hline & Agree8 & Take time out for others & 4.063 & 0.939 \\
\hline & Agreeg & Feel others' emotions & 4.184 & 0.961 \\
\hline & Agree1o & Make people feel at ease & 4.313 & 0.909 \\
\hline & Construct & & 43.433 & $5 \cdot 581$ \\
\hline \multirow[t]{11}{*}{ Conscientiousness } & Consc1 & Am always prepared & 4.147 & 0.991 \\
\hline & Consc2 & Leave my belongings around & 4.205 & 1.145 \\
\hline & Consc3 & Pay attention to details & 4.433 & 0.876 \\
\hline & Consc4 & Make a mess of things & $4 \cdot 35^{2}$ & 1.024 \\
\hline & Consc5 & Get chores done right away & 3.731 & 1.193 \\
\hline & Consc6 & Often forget to put things back in their proper place & 4.244 & 1.194 \\
\hline & Consc7 & Like order & $4 \cdot 349$ & 0.986 \\
\hline & Consc 8 & Shirk my duties & 4.686 & 0.727 \\
\hline & Consc9 & Follow a schedule & 4.071 & 1.118 \\
\hline & Conscio & Am exacting in my work & 4.653 & 0.641 \\
\hline & Construct & & 42.869 & 5.821 \\
\hline \multirow{3}{*}{$\begin{array}{l}\text { Emotional } \\
\text { stability }\end{array}$} & Emot1 & Get stressed out easily & 2.932 & 1.424 \\
\hline & Emot2 & Am relaxed most of the time & 2.949 & 1.291 \\
\hline & Emot3 & Worry about things & 1.901 & 1.032 \\
\hline
\end{tabular}


Personality and commitment as predictors of turnover intentions among Greek employees in the lodging industry

\begin{tabular}{|c|c|c|c|c|}
\hline Variables & Items & Description & Mean & SD \\
\hline & Emot4 & Seldom feel blue & 2.773 & 1.259 \\
\hline & Emot5 & Am easily disturbed & 3.191 & 1.289 \\
\hline & Emot6 & Get upset easily & $3 \cdot 382$ & 1.367 \\
\hline & Emot7 & Change my mood a lot & 3.299 & 1.414 \\
\hline & Emot8 & Have frequent mood swings & 3.429 & 1.426 \\
\hline & Emot9 & Get irritated easily & 3.045 & 1.372 \\
\hline & Emotio & Often feel blue & 3.368 & 1.355 \\
\hline & Construct & & 30.269 & 8.229 \\
\hline \multirow[t]{11}{*}{ Intellect } & Intelı & Have a rich vocabulary & 4.171 & 0.954 \\
\hline & Intel2 & Have difficulty understanding abstract ideas & 3.874 & 1.126 \\
\hline & Intel 3 & Have a vivid imagination & 3.872 & 1.111 \\
\hline & Intel $_{4}$ & Am not interested in abstract ideas & 3.426 & 1.314 \\
\hline & Intel 5 & Have excellent ideas & 3.784 & 0.953 \\
\hline & Intel6 & Do not have a good imagination & 4.164 & 1.039 \\
\hline & Intel7 & Am quick to understand things & 4.471 & 0.785 \\
\hline & Intel8 & Use difficult words & 2.952 & 1.321 \\
\hline & Intel9 & Spend time reflecting on things & 3.758 & 1.150 \\
\hline & Intelio & Am full of ideas & 3.896 & 1.022 \\
\hline & Construct & & 38.367 & 5.888 \\
\hline \multirow{7}{*}{$\begin{array}{l}\text { Occupational } \\
\text { commitment }\end{array}$} & OccComı & My occupation is important of my self-image & $5 \cdot 540$ & 1.644 \\
\hline & OccCom2 & I am proud to be in this occupation & 6.131 & 1.339 \\
\hline & $\mathrm{OccCom}_{3}$ & I regret having entered this occupation & 5.917 & 1.668 \\
\hline & $\mathrm{OccCom}_{4}$ & I am enthusiastic about my occupation & 5.695 & 1.553 \\
\hline & OccCom 5 & I dislike my occupation & 6.187 & 1.480 \\
\hline & OccCom6 & I do not identify with my occupation & $5 \cdot 717$ & 1.782 \\
\hline & Construct & & 5.864 & 1.183 \\
\hline \multirow[t]{7}{*}{$\begin{array}{l}\text { Organisational } \\
\text { commitment }\end{array}$} & OrgComı & $\begin{array}{l}\text { I would be very happy to spend the rest of my career with this } \\
\text { organisation }\end{array}$ & 4.024 & 2.205 \\
\hline & OrgCom2 & I really feel as if this organisation's problems are my own & 4.959 & 1.948 \\
\hline & OrgCom 3 & I do not feel a strong sense of "belonging" to my organisation & 5.208 & 2.036 \\
\hline & OrgCom 4 & I do not feel "emotionally attached" to this organisation & 5.122 & 2.098 \\
\hline & OrgCom 5 & This organisation has a great deal of personal meaning for me & 4.938 & 1.972 \\
\hline & OrgCom6 & I do not feel a strong sense of "belonging" to my organisation & 5.074 & 2.093 \\
\hline & Construct & & 4.888 & 1.545 \\
\hline \multirow{4}{*}{$\begin{array}{l}\text { Intention to leave } \\
\text { organisation }\end{array}$} & IntLOrg1 & How frequently do you think about leaving your current employer? & 3.668 & 2.090 \\
\hline & IntLOrg2 & $\begin{array}{l}\text { How likely it is that you would search for a job in another } \\
\text { organisation? }\end{array}$ & $4 \cdot 310$ & 2.234 \\
\hline & IntLOrg3 & $\begin{array}{l}\text { How likely it is that you will actually leave the organisation within } \\
\text { the next year? }\end{array}$ & $3 \cdot 974$ & 2.381 \\
\hline & Construct & & 3.984 & 2.035 \\
\hline \multirow{4}{*}{$\begin{array}{l}\text { Intention to leave } \\
\text { occupation }\end{array}$} & IntLOcc1 & How frequently do you think about getting out of your occupation? & 2.555 & 1.992 \\
\hline & IntLOcc2 & How likely it is that you will explore other career opportunities? & 3.062 & 2.133 \\
\hline & IntLOcc3 & $\begin{array}{l}\text { How likely it is that you will leave your present occupation within } \\
\text { the next year? }\end{array}$ & 2.415 & 2.002 \\
\hline & Construct & & 2.677 & 1.845 \\
\hline
\end{tabular}

\section{Measurement model}

Before the examination of the proposed hypothesis, measurement model has been evaluated by examining the internal consistency, convergent validity and discriminant validity. First indicators reliability was examined and loadings below 0.40 have been deleted (Extra1o, Agee1, Agee3, Agee6, Consc6, Emot2, Emot3, Emot4, Intell3, Intell4, Intell8) according to the recommendations of Hair et al., (2016). The construct reliability was measured by Cronbach's alpha, composite reliability, and the average variance extracted (AVE). The Cronbach's alpha of all nine constructs met the acceptable level of o.70, confirming the internal consistency. Composite reliability of all nine constructs meets the acceptable level of being greater than o.6o (Fornell \& Larcker, 1981). The average variance extracted 
ranges between $34 \%$ and $82 \%$, and so for the constructs of Agree, Consc, Exta and Intell is below the recommended level of 0.50 . A small increase on AVE was observed when deleting loadings lower than 0.40 but AVE still remained lower than 0.50 which is the minimum value required. An AVE lower than 0.50 though can be accepted in case that composite reliability is greater than 0.60 as according to Fornell and Larcker (1981) "on the basis of pn (composite reliability) alone, the researcher may conclude that the convergent validity of the construct is adequate, even though more than $50 \%$ of the variance is due to error" (p. 46). As the composite reliability of all nine constructs is above the recommended level of o.6o, the internal reliability of the measurement items is acceptable. The results for reliability and validity are presented in Table 4 .

Table 4. Construct reliability and validity analysis.

\begin{tabular}{lccc} 
& Cronbach's Alpha & Composite Reliability & AVE \\
\hline Agree & 0.768 & 0.831 & 0.414 \\
Consc & 0.774 & 0.821 & 0.340 \\
Emot & 0.841 & 0.878 & 0.511 \\
Extra & 0.805 & 0.848 & 0.388 \\
Intell & 0.736 & 0.812 & 0.390 \\
IntLOcc & 0.887 & 0.930 & 0.815 \\
IntLOrg & 0.896 & 0.935 & 0.827 \\
OccCom & 0.848 & 0.889 & 0.577 \\
OrgCom & 0.845 & 0.885 & 0.564 \\
\hline
\end{tabular}

Note: Leg.: Agree $=$ Agreeableness, Consc $=$ Conscientiousness, Emot $=$ Emotional stability, Extra $=$ Extraversion, Intell $=$ Intellect, IntLOcc = Intention to leave occupation, IntLOrg = Intention to leave organisation, OccCom = Occupational commitment, OrgCom = Organisation commitment, $A V E=$ Average variance extracted.

Discriminant validity was evaluated according to the recommended guidelines (Hair et al., 2016). Using the Fornell-Larcker criterion, the square root of AVE values were compared with the inter-construct correlation (Henseler et al., 2015; Hair et al., 2016). As it is shown in Table 5 all constructs had the square root of AVE values higher than the correlations among constructs.

Table 5. Discriminant validity analysis / Fornell-Larcker Criterion.

\begin{tabular}{llllllllll} 
& Agree & Consc & Emot & Extra & Intell & IntLOcc & IntLOrg & OccCom & OrgCom \\
\hline Agree & $\mathbf{0 . 6 4 3}$ & & & & & & & & \\
Consc & 0.391 & $\mathbf{0 . 5 8 3}$ & & & & & & & \\
Emot & 0.139 & 0.287 & $\mathbf{0 . 7 1 5}$ & & & & & & \\
Extra & 0.380 & 0.242 & 0.234 & $\mathbf{0 . 6 2 3}$ & & & & & \\
Intell & 0.416 & 0.506 & 0.214 & 0.454 & $\mathbf{0 . 6 2 5}$ & & & & \\
IntLOcc & -0.155 & -0.178 & -0.235 & -0.150 & -0.104 & $\mathbf{0 . 9 0 3}$ & & & \\
IntLOrg & -0.144 & -0.139 & -0.257 & -0.112 & -0.080 & 0.499 & $\mathbf{0 . 9 1 0}$ & & \\
OccCom & 0.263 & 0.233 & 0.166 & 0.269 & 0.215 & -0.661 & -0.352 & $\mathbf{0 . 7 5 9}$ & \\
OrgCom & 0.219 & 0.257 & 0.207 & 0.194 & 0.170 & -0.394 & -0.653 & 0.483 & $\mathbf{0 . 7 5 1}$ \\
\hline
\end{tabular}

Note: Values in bold italics represent Square-root of AVE. Leg.: Agree = Agreeableness, Consc = Conscientiousness, Emot $=$ Emotional stability, Extra = Extraversion, Intell = Intellect, IntLOcc = Intention to leave occupation, IntLOrg = Intention to leave organisation, OccCom = Occupational commitment, OrgCom = Organisation commitment. 
Discriminant validity has also been assessed by the HTMT approach (Table 6) and all values where lower than 0.90 (Hair et al., 2016; Henseler et al., 2015), Thus discriminant validity of the model has been confirmed.

Table 6. Discriminant validity analysis / HTMT Ratio.

\begin{tabular}{llllllllll} 
& Agree & Consc & Emot & Extra & Intell & IntLOcc & IntLOrg & OccCom & OrgCom \\
\hline Agree & & & & & & & & & \\
Consc & 0.426 & & & & & & & \\
Emot & 0.164 & 0.360 & & & & & & \\
Extra & 0.432 & 0.274 & 0.261 & & & & & \\
Intell & 0.517 & 0.573 & 0.289 & 0.585 & & & & \\
IntLOcc & 0.174 & 0.199 & 0.274 & 0.172 & 0.123 & & & \\
IntLOrg & 0.162 & 0.143 & 0.280 & 0.119 & 0.094 & 0.554 & & \\
OccCom & 0.306 & 0.255 & 0.200 & 0.321 & 0.275 & 0.749 & 0.394 & & \\
OrgCom & 0.257 & 0.264 & 0.222 & 0.214 & 0.196 & 0.441 & 0.730 & 0.568 & \\
\hline
\end{tabular}

Note: Leg.: Agree = Agreeableness, Consc = Conscientiousness, Emot = Emotional stability, Extra = Extraversion, Intell = Intellect, IntLOcc = Intention to leave occupation, IntLOrg = Intention to leave organisation, OccCom = Occupational commitment, OrgCom = Organisation commitment.

Lastly, collinearity of variables has been examined. Every item's variance inflation factor (VIF) was under 3,3 , implying that multicollinearity was not an issue.

\section{Structural Model and hypothesis testing}

The goodness of the model is determined by the strength of each structural path determined by $\mathrm{R}^{2}$ value for dependent variable, the value of $\mathrm{R}^{2}$ should be equal to or over o.1. Using bootstrapping (500o bootstrap samples) the results in Table 6 show that all $\mathrm{R}^{2}$ are above o.1. Thus, predictive capability of the structure model is established. Moreover, the predictive relevance of the endogenous constructs is examined by the $\mathrm{Q}^{2}$ value, which should be greater than o. Using blindfolding the results on the same table (Table 7), show that prediction of the constructs is significant. Model fit was assessed by the SRMR value which is 0.064 and it confirms the model fit as the SRMR value is lower than the o.1o threshold (Hair et al., 2016).

Path coefficient, total effect, direct effect, indirect effect and significance of the hypothesised relationships have been assessed to test the postulated hypothesis. The results revealed that hypothesis Hia has been partially confirmed. Among the four traits (Agree, Con, Emot and Extra), only emotional stability (Emot) had a significant impact on intention to leave the organisation $(\beta=-0.095, t=3.307$, $p=0.001)$. Hypothesis $\mathrm{Hib}$ examined whether intellect has a positive impact on intention to leave the organisation (IntLOrg). Results revealed that even though the relationship is positive $(\beta=-0.020, t=0.521$, $p=0.602$ ), it is not significant, and thus Hib was not supported (Table 7 ).

Hypothesis Hza evaluated if a strong negative relationship exists between organisational commitment (OrgCom) and intention to leave organisation (IntLOrg). Results confirmed this hypothesis $(\beta=-0.597$, $t=20.455, p=\leq 0.001$;) and thus hypothesis H2a has been supported. Moreover, hypothesis H2b examines if a strong negative correlation exists between occupational commitment and intention to leave organisation. Results also confirmed this hypothesis $(\beta=-0.096, t=2.551, p=0.011)$, supporting $\mathrm{H} 2 \mathrm{~b}$ too. 
The results for hypothesis Hza are presented in Table 7, whereas results of $\mathrm{H}_{2} \mathrm{~b}$ are presented in Table 8.

Table 7. Path Coefficient.

\begin{tabular}{|c|c|c|c|c|c|c|c|}
\hline & $\beta$ & SD & T stat & P values & $2.50 \%$ & $97.50 \%$ & $\mathbf{f}^{2}$ \\
\hline Agree $\rightarrow$ IntLOrg & -0.030 & 0.034 & 0.881 & 0.378 & -0.096 & 0.037 & 0.008 \\
\hline Consc $\rightarrow$ IntLOrg & 0.056 & 0.039 & 1.420 & 0.156 & -0.021 & 0.133 & 0.002 \\
\hline Emot $\rightarrow$ IntLOrg & -0.095 & 0.029 & 3.307 & 0.001 & -0.151 & -0.037 & 0.047 \\
\hline Extra $\rightarrow$ IntLOrg & 0.023 & 0.033 & 0.695 & 0.487 & -0.040 & 0.088 & 0.001 \\
\hline Intell $\rightarrow$ IntLOrg & 0.020 & 0.039 & 0.521 & 0.602 & -0.052 & 0.096 & 0.001 \\
\hline OrgCom $\rightarrow$ IntLOrg & -0.597 & 0.029 & 20.455 & $\leq \mathbf{0 . 0 0 1}$ & -0.654 & -0.539 & 0.585 \\
\hline OccCom $\rightarrow$ IntLOrg & 0.155 & 0.037 & 4.182 & $\leq \mathbf{0 . 0 0 1}$ & 0.071 & 0.217 & 0.025 \\
\hline IntLOcc $\rightarrow$ IntLOrg & 0.380 & 0.039 & $9 \cdot 706$ & $\leq \mathbf{0 . 0 0 1}$ & 0.302 & 0.457 & 0.188 \\
\hline OccCom $\rightarrow$ IntLOcc & -0.661 & 0.025 & 26.605 & $\leq \mathbf{0 . 0 0 1}$ & -0.705 & -0.607 & 0.519 \\
\hline OrgCom $\rightarrow$ OccCom & 0.482 & 0.035 & 13.775 & $\leq \mathbf{0 . 0 0 1}$ & 0.410 & 0.547 & 0.302 \\
\hline Agree $\rightarrow$ OrgCom & 0.112 & 0.041 & 2.733 & 0.006 & 0.031 & 0.189 & 0.012 \\
\hline Consc $\rightarrow$ OrgCom & 0.168 & 0.043 & 3.910 & $\leq 0.001$ & 0.081 & 0.248 & 0.027 \\
\hline Emot $\rightarrow$ OrgCom & 0.128 & 0.037 & 3.492 & $\leq \mathbf{0 . 0 0 1}$ & 0.056 & 0.197 & 0.014 \\
\hline Extra $\rightarrow$ OrgCom & 0.097 & 0.042 & 2.313 & 0.021 & 0.014 & 0.176 & 0.006 \\
\hline \multirow[t]{2}{*}{ Intell $\rightarrow$ OrgCom } & -0.035 & 0.046 & 0.764 & 0.445 & -0.139 & 0.042 & 0.001 \\
\hline & $\mathbf{R 2}$ & $\mathbf{Q 2}_{2}$ & & & & & \\
\hline IntLOcc & 0.437 & 0.347 & & & & & \\
\hline IntLOrg & 0.533 & 0.431 & & & & & \\
\hline OcCom & 0.232 & 0.131 & & & & & \\
\hline OrgCom & 0.106 & 0.057 & & & & & \\
\hline
\end{tabular}

Note: Leg.: Agree = Agreeableness, Consc = Conscientiousness, Emot = Emotional stability, Extra = Extraversion, Intell = Intellect, IntLOcc = Intention to leave occupation, IntLOrg = Intention to leave organisation, OccCom = Occupational commitment, OrgCom = Organisation commitment.

\section{Mediation analysis (hypothesis $\mathrm{H}_{2 \mathrm{C}}$ )}

Mediation analysis was performed to assess the mediation role of intention to leave occupation (IntLOcc) on the relationship between occupational commitment (OcCom) and intention to leave organisation (IntLOrg). The results (Table 8) revealed that the total effect of OcCom on IntLOrg was significant (H2b: $\beta=-0.096, t=2.551, p=0.011)$. In the presence of IntLOc the impact of OcCom on IntLOrg remains significant $(\beta=0.155, t=4.182, p=\leq 0.001)$. The indirect effect of OcCom on IntLOrg was found significant $(\beta=-0.251, t=9.325, p=\leq 0.001)$, too. This shows that the relationship between OcCom and IntLOrg is partially mediated by IntLOc and, thus, H2c Hypothesis has been supported, which in other words means that high levels of occupational commitment leads to lower levels of intention to leave the occupation, which in turn leads to lower levels of intention to leave the organisation. Thus, some of the effects of occupational commitment on intention to leave organisation is explained through intention to leave the occupation. 
Table 8. Mediation analysis.

\begin{tabular}{|c|c|c|c|c|c|c|}
\hline \multicolumn{2}{|c|}{ Total effect (OccCom-> IntLOrg) } & \multicolumn{5}{|c|}{ Direct effect (OccCom-> IntLOrg) } \\
\hline$\beta$ & P value & $\beta$ & P valu & & & \\
\hline \multirow[t]{3}{*}{-0.096} & 0.011 & 0.155 & $\leq 0.00$ & & & \\
\hline & & \multicolumn{5}{|c|}{ Indirect effect (OccCom-> IntLOrg) } \\
\hline & & $\beta$ & SD & T value & $P$ value & BI $[2,5 \% ; 97,5 \%]$ \\
\hline \multicolumn{2}{|c|}{ H2c: OccCom-> IntLOcc-> IntLOrg } & -0.251 & 0.027 & $9 \cdot 325$ & $\leq 0.001$ & $-0.308 ;-0.198$ \\
\hline
\end{tabular}

Note: Leg.: IntLOcc = Intention to leave occupation, IntLOrg = Intention to leave organisation, OccCom = Occupational commitment, OrgCom = Organisation commitment

\section{Moderation effect (hypothesis $\mathrm{H} 2 \mathrm{~d}$ )}

One of the study's goals was to examine the moderating effect of occupational commitment on the relationship between organisational commitment and intention to leave the organisation. Results revealed that OcCom actually is a moderator on the relationship between OrgCom and IntLOrg ( $\beta=-$ $0.067, t=2.573, p=0.010)$. Regarding the size of the moderation effect, the interaction term has a negative effect on IntLOrg $(-0,067)$, whereas the simple effect of OrgCom on IntLOrg is $(-0,592)$. These results suggest that the relationship between OrgCom and IntLOrg is (-0.592) in an average level of occupational commitment. For higher levels of OcCom (OcCom increased by one standard deviation point), the relationship between OrgCom and IntLOrg increases by the size of interaction term (-0.592$0.067=-0.659$ ). On the other hand, for lower levels of OcCom (OcCom decreased by one standard deviation point), the relationship between OrgCom and IntLOrg becomes (-0.592+0.067=)-0.525 (Figure 10). Therefore, hypothesis $\mathrm{H} 2 \mathrm{~d}$ has been confirmed.

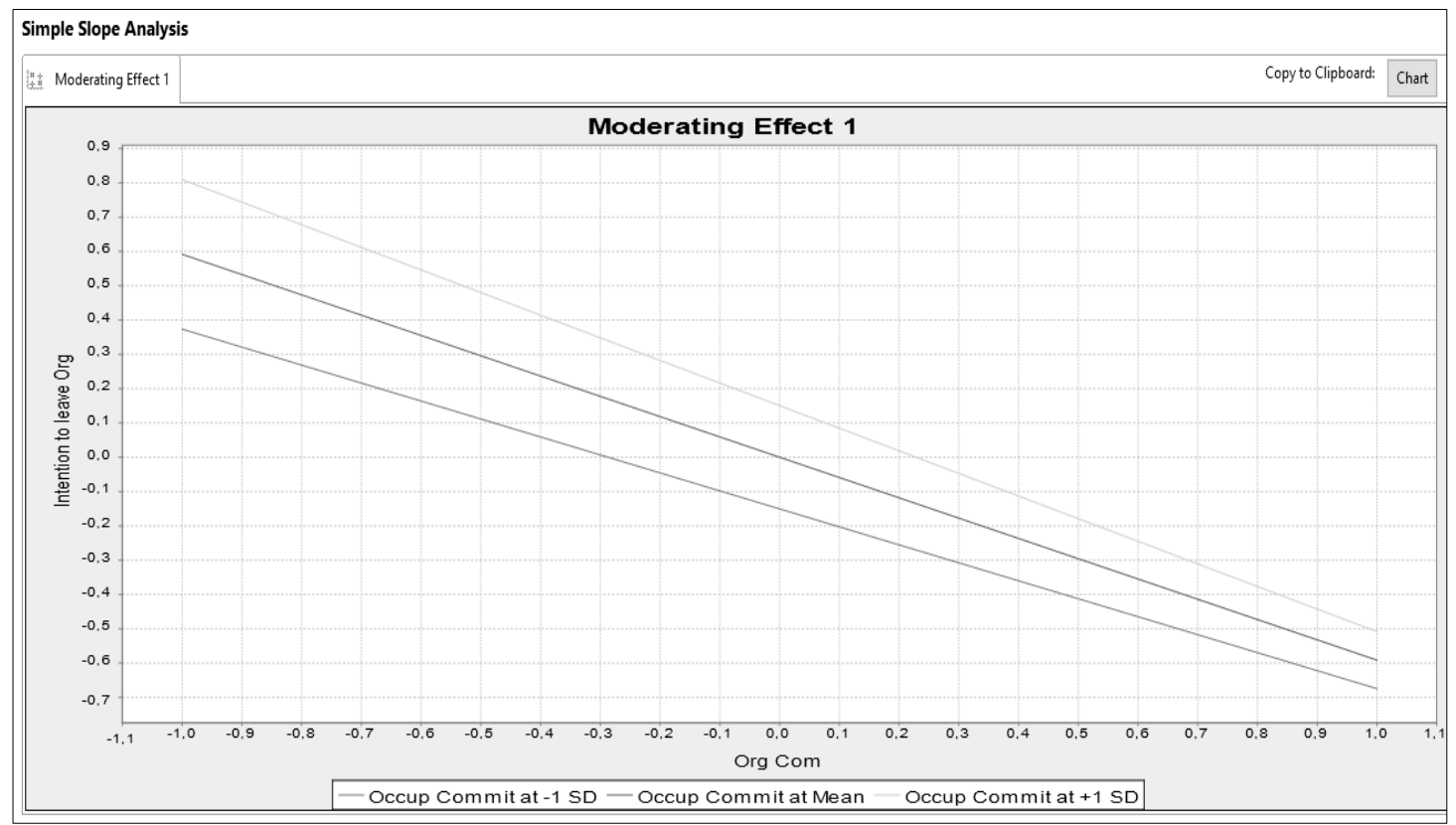

Figure 1. Moderating effect.

Note: The middle slope represents the mean value of OccCom, while the upper one +1 SD and the lower one -1 SD from the mean value. 
Hypothesis $\mathrm{H}_{3}$ a has been supported, as all four traits (Agree, Con, Emot and Extra) of FFM are found to have a significant positive impact on $\operatorname{InLOrg}[(\beta=0.112, t=2.733, p=0.006) ;(\beta=0.168, t=3.910, p=\leq 0.001)$; $(\beta=0.128, t=3.492, p=\leq 0.001) ;(\beta=0.097, t=2.313, p=0.021)]$, respectively. Hypothesis $\mathrm{H}_{3} b$, however, has not been supported, as despite a negative relationship between intellect and OrgCom, that relationship was insignificant $(\beta=-0.035, t=0.764, p=0.445)$. All path coefficients are presented in Figure 11.

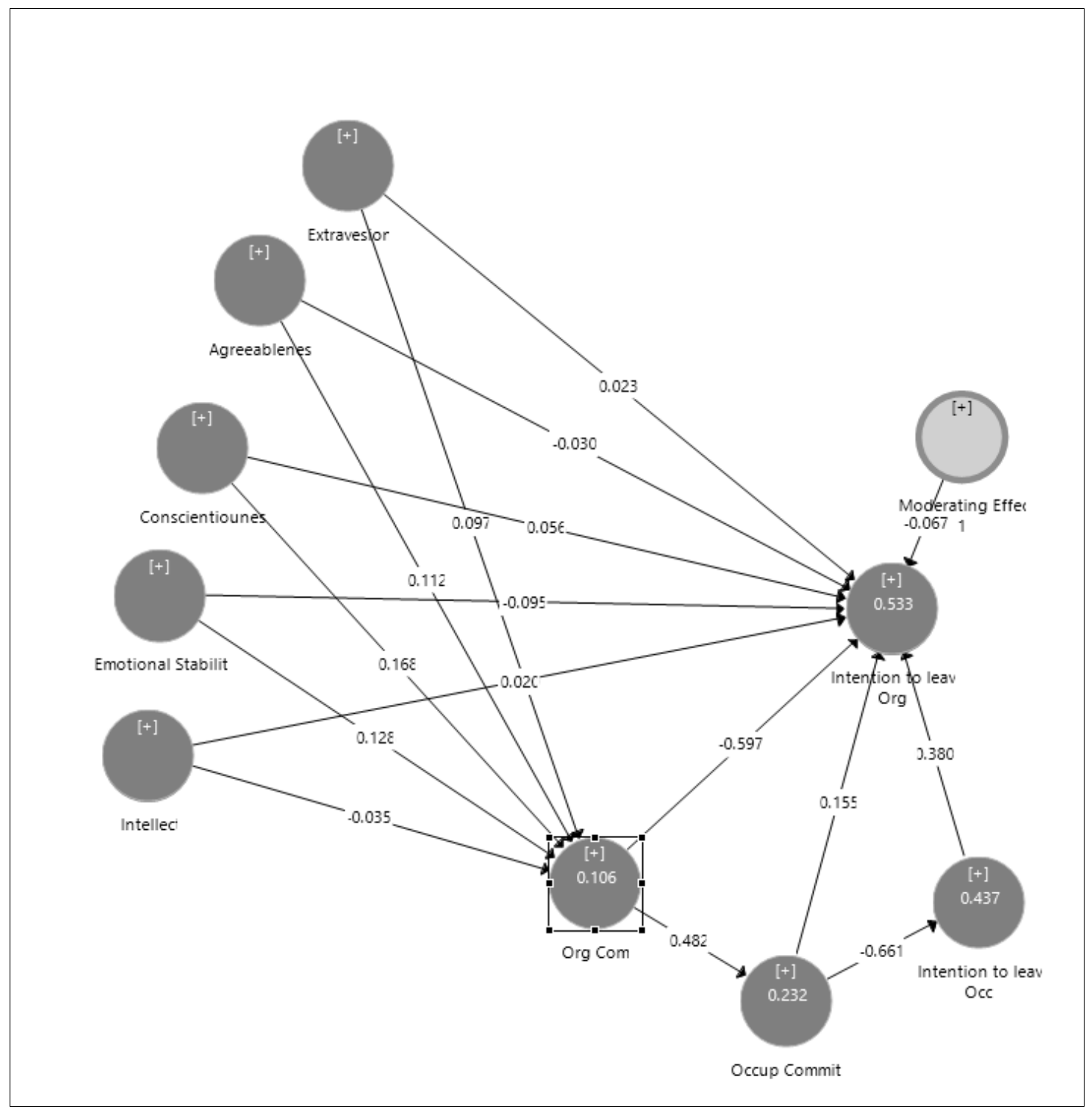

Figure 2. Dispositional turnover model.

\section{Discussion}

The current study's results revealed that of the five traits of FFM, only emotional stability has a significant negative effect on the intention to the leave the organisation, thus partially confirming Hypothesis Hia and failing to confirm Hypothesis Hib. Present results will be compared with the 
findings of previous studies by Zimmerman (2008), Salgado (2002), Timmerman (2006) as well as Ariyabuddiphongs and Marican (2015).

Present results are partially similar to Zimmerman's (2008) meta-analysis, who found strong negative correlation between four of the five dimensions of FFM (i.e., extraversion, conscientiousness and emotional stability, agreeableness) and the intention to leave the organization. Remarkably, among those three dimensions of FFM, emotional stability was the best predictor, followed by conscientiousness and extraversion. Salgado (2002) in his meta-analysis found that emotional stability, conscientiousness, and agreeableness are determinants of actual turnover, whereas Timmerman (2006) in a study conducted among customers service representative in US found strong correlations only between extraversion and openness to experience (intellect) and actual turnover.

Little previous research has examined the impact of FFM traits on intention to leave the organisation generally and more specifically, in the hospitality industry. To the author's best knowledge only Ariyabuddiphongs and Marican (2015) have examined the relationship between the Big Five personality traits and turnover intentions. In their study using regression analysis, they have examined personality as one set and they found that personality negatively predicts turnover intentions among hotel employees in Thailand.

To cover this gap, the present study examined the relationship between personality and turnover intention among lodging employees and found that among the big five traits, only emotional stability can predict intention to leave the organisation, in a way that employees high in emotional stability are less likely to quit. The aforementioned results are important for staff selection in the accommodation sector, as they imply that personality can contribute to predicting turnover intentions only in terms of emotional stability.

The small effect size of emotional stability should not be neglected mainly due to two reasons. First, in the context of psychological research it is more or less foreseeable (for a discussion see Cumming, 2012, and Funder \& Ozer, 2019) and, second, underestimation of results of small effect sizes might lead to misleading results and information, which otherwise would be useful in the improvement of theory and practice (Funder \& Ozer, 2019; Ahadi \& Diener, 1989; De Boeck \& Jeon, 2018).

These results seem reasonable as in the hospitality industry employees are often asked to cope with stressful situations, to positively face the challenges, and stay calm even in the most demanding situations. Therefore, if employees are not emotionally stable, they will face difficulties to stay in a hospitality organisation and they will be more likely to leave regardless of the working conditions. However, further research on the topic in the hospitality context is needed, as empirical evidence is limited.

Moreover, the results indicate that the work attitude of organisational commitment has a significant negative effect on the intention to leave the organisation. More specifically, it was revealed that organisational commitment predicts intentional turnover behaviour in a way that people high on organisational commitment are less likely to have turnover intentions. These results are in accordance with previous research in the hospitality context (Cho et al., 2009; Yang, 2010; Zopiatis et al., 2014; Park \& Min, 2020) and add to the existing hospitality literature especially in terms of the Greek literature where little research on the topic has been conducted, so far. The effect size of organisational commitment on intention to leave organisation is quite large $\left(f^{2}=0,585\right)$, which implies that 
organisational commitment has a large effect on turnover intentional behaviour of employees in the context of tourism and more specifically in the accommodation sector.

Thus, the present findings from Greece are in line with previous research from other countries. This provides added assurance to hospitality managers to base their staffing decisions by assessing commitment of job candidates for limiting turnover.

Furthermore, occupational commitment was found to negatively affect the intention to leave the organisation in a way that people with high occupational commitment have less intention to leave organisation. These results are in accordance with previous research from other sectors (Lee et al., 2000; Chang et al., 2007) and add to the hospitality literature as there was no previous research on the topic in the hospitality context. The effect size of occupational commitment $\left(f^{2}=0.025\right)$ is reasonably smaller than that of organisational commitment, but still of notable importance.

These results seem reasonable considering that people who are committed to their occupation are more motivated to stay in the organisation and apply their professional skills within such environment. Therefore, assessing occupational commitment as a selection criterion by hiring managers might be useful in the unstable hospitality context, but further research on the topic is needed to confirm our results in other countries, as well, before we can use these results safely.

In addition, this study's results revealed a mediating role of the intention to leave the occupation on the relationship between occupational commitment and the intention to leave the organisation, supporting Hypothesis H2c. More specifically, a partial mediation was revealed which means that some of the effect of occupational commitment on intention to leave the organisation can be explained through intention to leave the occupation. More specifically, a low intention to leave the occupation leads to higher occupational commitment, which in turn leads to lower levels of intention to leave the organisation.

Studies have so far neglected to examine occupation commitment-related variables and, therefore, the research is very limited on the topic (Lee et al., 2000). Interestingly, the present results are different from previous researchers who found full mediation in their studies (Lee et al., 2000; Chang et al., 2007). Even though the present study found partial mediation, the effect size of occupational commitment on intention to leave the organisation is smaller when intention to leave occupation is not considered in the equation. $\left(f^{2}=0,023\right)$. However, in the presence of intention to leave occupation the effect size of occupational commitment on intention to leave organisation is is much greater $\left(f^{2}=0,165\right)$.

These results indicate that intention to leave the occupation is a much better predictor for intention to leave the organisation. This means that intentions of employees who are committed to their occupation cannot be safely predicted if their intention to leave the occupation is not measured simultaneously. An occupationally committed hospitality employee might not intend to leave an organisation if they feel that the organisation gives them the opportunity to apply their professional skills, else they might continue within the same occupation by changing their employer for better opportunities. Therefore, it cannot be safely predicted whether an employee will quit only by measuring occupational commitment, but also by considering intention to leave the occupation, as well. These results add to the hospitality literature as no other research on the topic exists.

Regarding Hypothesis $\mathrm{H} 2 \mathrm{~d}$ it was found that occupational commitment can affect the strength of the relationship (moderating role) between organisational commitment and the intention to leave the 
organisation. The results indicate that individuals who are committed to organisation are less willing to quit and this relationship is getting stronger for those who are highly committed to their occupation. According to Cohen's (1988) classification of effect size, the effect size of the moderator $\left(f^{2}=0.018\right)$ was not significant. However, as has already been discussed, in the moderation literature the average value of $\mathrm{f}^{2}$ in the case of moderators is 0.009 (Aguinis, Beaty, Boik, \& Pierce, 2005), which lead us to adopt less strict thresholds like the ones of Kenny's (2016) in accordance with the recommendations of Hair, Sarstedt, et al. (2017). Thus, the effect size of the moderator can be considered as a medium, considering that the size of the effect should reflect the research aims and the evidence of the current literature. These results indicate that the more a hospitality employee is occupationally committed, the less he/she intends to quit. These findings are in line with the results of similar research projects (Lee et al., 200o; Yousaf et al., 2015) and add to the hospitality literature as no evidence on this issue exists within the hospitality industry.

The above results imply that the work attitude of commitment (either in terms of organisational commitment-related variables or in terms of occupational commitment-related variables) highly contributes to predict the intention to leave the organisation in the hospitality context.

Hypothesis $\mathrm{H}_{3}$ a was confirmed as a strong positive relationship between four of the five traits (i.e., extraversion, agreeableness, emotional stability, conscientiousness) and organisational commitment was revealed. The impact of intellect on organisational commitment, however, despite being negative, was insignificant and thus failed to support Hypothesis $\mathrm{H}_{3} \mathrm{~b}$. These results are similar to previous yet limited studies. More specifically, the present results are in accordance with Erdheim et al. (2006), Zettler et al. (2011), Spagnoli and Caetano (2012), Silva (2006), and Choi et al. (2015) with respect to extraversion. Regarding agreeableness, the present results are in line with Choi et al. (2015), but in contrast with Zettler et al. (2011). Concerning conscientiousness, the present results are similar to those of Choi et al. (2015), Erdheim et al. (2006), Silva (2006), and Farrukh et al. (2017). Regarding emotional stability, this study found the same results as Erdheim et al. (2006), Silva (2006), and Choi et al. (2015). Finally, as far as intellect is concerned the present results are in contrast with both Choi et al. (2015) and Spagnoli and Caetano (2012), as there was no significant relationship between intellect and organisational commitment.

The effect sizes of personality dimensions on organisational commitment are quite small, which is not uncommon according to the analysis provided regarding Hypothesis H1. More specifically, among the personality traits conscientiousness had the highest effect size $\left(f^{2}=\mathbf{0 . 0 2 7}\right)$ on organisational commitment, although it is still considered small. The effect size of agreeableness $\left(f^{2}=0.012\right)$ and emotional stability $\left(f^{2}=0.014\right)$ on organisational commitment can be considered very small. However, extraversion $\left(f^{2}=0.006\right)$ and intellect $\left(f^{2}=0.001\right)$ can be considered as having no effect as they are smaller even than the lowest threshold that was proposed for moderators $\left(f^{2}=0.009\right)$. Consequently, when the research aim is to predict organisational commitment, conscientiousness can be considered the most valuable predictor, followed by agreeableness and emotional stability.

Silva (2006) first reported a positive correlation between conscientiousness, extraversion and emotional stability, which was also confirmed by the present study. The latter also revealed that conscientiousness is a predictor of organisational commitment. This study's results add to the limited literature regarding the dispositional feature of commitment especially in the hospitality context. 


\section{Conclusion}

In sum, this study examined the dispositional feature of turnover in the Greek accommodation sector. For this purpose, personality, commitment and turnover intentions among 665 lodging employees were examined. After analysing the research data, emotional stability was found to be a predictor of organisational turnover intentions. In addition, conscientiousness was found to predict organisational commitment. Organisational commitment and intention to leave the occupation were found to be strong predictors of organisational turnover intentions, as well.

These findings provide useful input to hiring managers in the hospitality sector by helping them to tackle the high staff turnover rates in this particular sector both in Greece and globally. The present study also adds to the limited literature and broadens its scope as previous research on turnover models is restricted to organisational and situational factors. Additionally, this study provides primary data concerning turnover, commitment, and personality about Greek hospitality employees, which can be compared with future surveys in other countries and cultures.

\section{Practical and theoretical implications}

The present research has important implications for both human resource managers in the accommodation sector and academic research in terms of turnover models.

Hospitality-related research has shown that selection procedures in hospitality industry are quite poor and even though the use of structured tests, like personality and attitudes tests, has widely been acknowledged, the use of structured tests is very limited (Armstrong \& Taylor, 2014). Especially in terms of turnover, personality has rarely been assessed. Therefore, the present study results encourage managers to consider personality during staff selection.

Hospitality managers - especially those in charge of hiring new employees - can benefit from the present findings by considering the following points. First of all, HR managers will be better supported in discussing staffing needs with the respective department heads of a hotel. Emphasizing on personality and commitment propensities will help in preparing more accurate job profiles. Second, HR managers can apply personality tests in the selection procedure for screening job candidates in a more efficient way. More particularly, the use of standardised psychometric tests will help in better identifying the more suitable candidates.

According to our results, candidates high in emotional stability and conscientiousness should be preferred in the hospitality industry as they are expected to express lower intention to leave the organisation. In this way, recruiters may contribute to decreasing high turnover rates, which represent a pressing problem for the industry. Furthermore, as employee turnover is accompanied by huge direct and indirect costs, hiring on turnover intention criteria can lead to a reduction of these damaging effects, as well. Moreover, by administrating personality tests that assess all five traits, recruiters will gain additional information about other traits that have practical implications for other work-related outcomes. Is should be stressed, however, that as recommended by Hughes and Batey (2017), personality tests should not be used alone as a selection tool, but they should always be combined with other selection methods. Therefore, people that fulfil all the other established hiring criteria and are at the same time high in emotional stability and conscientiousness, should be preferred.

Managers being aware of commitment and turnover tendency of an employ may be alerted earlier and apply more personalised practices to prevent turnover behaviour. At the same time managers will accept 
that some of the quits are out of their control. More specifically some quits are related to employee ad se, and therefore even the best management practices cannot prevent employee turnover in some cases. Managers are also encouraged to assess candidates' occupational commitment-related variables during the selection procedure. Employees that have intentions to leave occupation are prone to leave the organisation as well. This might be explained by the fact that it is difficult for an employee to find a different job in the same organisation. The connection of candidates with their occupation may be valuable while making managerial decisions in an organisational level. If managers are able to detect that a valuable employee has intentions to leave their occupation, then they may try to find a sustainable solution for both parts, in order to avoid losing a key employee at all.

The findings of the present study highlight the usefulness of psychometrics in the staff selection process of hospitality businesses with the aim of reducing the sector's high turnover rates. However, the limited financial resources of small accommodation businesses - which are the majority among this sector the lack of independent human resource departments and the special education and training that is required to evaluate personality, should not be ignored. Co-operation with qualified consultants in the selection process might be a solution, however, it would be best if HRM professionals themselves will master these techniques and be able to include them in their day-to-day work. In addition, educational programs on human resource management in tourism should be enriched with staff selection courses, so that future HRM professionals will be able to handle these issues in the proper manner and to be able to make the most of the available literature, as most of the times research papers seem to have only theoretical implications but no actionable advice. Finally, tourism-related government agencies should put more emphasis on employment issues by developing training programs for HRM professionals. These programs should highlight the importance of using structured selection tools, like personality tests, during the hiring process.

Through this study, it was intended to broaden our horizons regarding turnover models in the hospitality context focusing on individuals' differences. This study confirmed the contribution of personality to turnover models. Personality was also connected with the work attitude of commitment contributing to the organisational behaviour theory. The connection between different foci of commitment provided further data on the theory of work attitudes, as well. The present study provided primary data regarding personality, commitment, and intention to leave the organisation within the Greek accommodation sector. Therefore, our study highly contributed in the growing body of literature in the hospitality context and more specifically in the context of hospitality organisational behaviour.

\section{Limitations and future research}

A limitation of the present research is that it is based on a non-probability sample, as respondents were recruited through Facebook and, thus, the results cannot be safely generalised. Even though recent literature states that samples through Facebook are acceptable and present equally representative samples as traditional sampling methods, there is only limited literature on this topic. Self-selection bias is might also be a limitation of online surveys, as in any given online community some individuals tend to participate more frequently in online surveys than others and this might lead to systematic bias (Sekaran \& Bougie, 2016).

Also, the majority of the respondents were employees of large upscale four- and five-star hotels, whereas the large majority of tourist accommodation in Greece comprises quite smaller businesses. Nevertheless, the present sample can be considered quite representative of Greek reality, as employees of different accommodation businesses, different positions and different locations in Greece have 
participated in the present survey. Thus, this study provides valid evidence for readers interested in further investigating turnover issues in the hospitality industry.

A limitation of the present study is that turnover intention and not actual turnover has been measured. Even though there is evidence that actual turnover can be measured effectively by intention to leave the organisation, it should not become a surrogate of turnover (Tett \& Meyer, 1993). The fact that previous research found a strong correlation of different personality traits of FFM with actual turnover, reveals the need of further focus on the topic of measuring actual turnover in the hospitality industry. Therefore, actual turnover should be measured, as well.

Personality in this study was measured through broad traits, whereas there is evidence that in some cases, more narrow traits become more useful in the organisational field. As the focus of the present research was not in a specific job, but on different jobs in the broader accommodation sector, the use of broad traits seems appropriate. More narrow traits would be more appropriate in the case of focusing on a particular job's specific dimensions (Spector, 2012). In addition, as claimed previously personality can be predicted in general terms and, thus, using more broad traits seems to be more effective. However, future research on specific jobs in lodging industry is highly encouraged.

Finally, a limitation of the study is that all variables have been measured with self-reports and, therefore, the absence of faking cannot be guaranteed. For minimizing this problem, participants received instructions to honestly answer how they see themselves and not how they wish to be in the future, highlighting that their responses will be kept in absolute confidence. However, future research on the topic with different research methods (e.g. observer ratio) for assessing personality might be valuable, as well.

The current study's results will support academics to further examine personality and commitment (both organisational and occupational) in terms of turnover models in hospitality, as the related literature is very limited. Considering that the present study covered the Greek accommodation sector, future studies in other countries and other hospitality sectors would help to generalise these findings. This may enable researchers to find differences that might exist in personality and commitment features among different cultures in the hospitality industry.

\section{Acknowledgements}

The present study is part of the doctoral research of the first author who is a Ph.D. student in the Business Administration Department, University of Patras, and receives a scholarship from the Greek State Scholarships Foundation (IKY). This research is co-financed by Greece and the European Union (European Social Fund- ESF) through the Operational Programme «Human Resources Development, Education and Lifelong Learning» in the context of the project "Strengthening Human Resources Research Potential via Doctorate Research" (MIS-5000432), implemented by the State Scholarships Foundation (IKY).

\section{References}

Aguinis, H., Beaty, J. C., Boik, R. J., \& Pierce, C. A. (2005). Effect size and power in assessing moderating effects of categorical variables using multiple regression: A 30-year review. Journal of Applied Psychology, 9o(1), 94-107. doi: 10.1037/o021-9010.90.1.94

Ahadi, S., \& Diener, E. (1989). Multiple determinants and effect size. Journal of Personality and Social Psychology, 56(3), 398-406. doi: 10.1037/0022-3514.56.3.398 
Albrecht, S. L., Bakker, A. B., Gruman, J. A., Macey, W. H., \& Saks, A. M. (2015). Employee engagement, human resource management practices and competitive advantage. Journal of Organizational Effectiveness, 2(1), 7-35. doi:10.1108/JOEPP-08-2014-0042

Allen, N. J. (2016). Commitment as a multidimensional construct. In J. P. Meyer (Ed.), Handbook of employee commitment (pp. 28-42). Northampton, MA: Edward Elgar Publishing, Inc.

Anastassova, L., \& Purcell, K. (1995). Human resource management in the Bulgarian hotel industry: from command to empowerment? International Journal of Hospitality Management, 14(2), 171-185. doi:10.1016/o278-4319(95)ooo20-D

Anthoine, E., Moret, L., Regnault, A., Sébille, V., \& Hardouin, J. B. (2014). Sample size used to validate a scale: a review of publications on newly-developed patient reported outcomes measures. Health and quality of life outcomes, 12(1), 1-10. doi: 10.1186/s12955-014-0176-2

Ariyabuddhiphongs, V., \& Marican, S. (2015). Big Five personality traits and turnover intention among Thai hotel employees. International Journal of Hospitality $\mathcal{E}$ Tourism Administration, 16(4), 355-374. doi: 10.1080/15256480.2015.1090257

Armstrong, M., \& Taylor, S. (2014). Armstrong's Handbook of Human Resource Management Practice. USA: Kogan Page Publishers.

Balogun, A. G. \& Agesin B. E. (2014). Withdrawal cognition among workers in distressed banks: roles of perceived organization support and inequality. African Journal for Psychological Study of Social Issues, $17(2)$, 78-87.

Barrick, M. R., \& Mount, M. K. (1991). The big five personality dimensions and job performance: a metaanalysis. Personnel psychology, 44(1), 1-26. doi: 10.1111/j.1744-6570.1991.tboo688.x

Barrick, M. R., Mount, M. K., \& Judge, T. A. (2001). Personality and performance at the beginning of the new millennium: What do we know and where do we go next? International Journal of Selection and assessment, 9(1-2), 9-30. doi: 10.1111/1468-2389.0016o

Barrick, M. R., \& Zimmerman, R. D. (2005). Reducing voluntary, avoidable turnover through selection. Journal of Applied Psychology, 9o(1), 159.

Bergman, M. E., \& Jean, V. A. (2016). Individual differences as causes of the development of commitment. In J. P. Meyer (Ed.), Handbook of employee commitment (pp. 28-42). Northampton, MA: Edward Elgar Publishing, Inc.

Blau, G., \& Lunz, M. (1998). Testing the incremental effect of professional commitment on intent to leave one's profession beyond the effects of external, personal, and work-related variables. Journal of Vocational Behavior, 52(2), 260-269. doi: 10.1006/jvbe.1997.1601

Bluedorn, A. C. (1982). A unified model of turnover from organizations. Human relations, 35(2), 135-153. doi: 10.1177/001872678203500204

Boella, M.J., \& Goss-Turner, S. (2019). Human resource management in the hospitality industry: A guide to best practice (9th ed.). UK: Routledge.

Bryant, P. C., \& Allen, D. G. (2013). Compensation, benefits and employee turnover: HR strategies for retaining top talent. Compensation \& Benefits Review, 45(3), 171-175. doi: 10.1177/o886368713494342

Carbery, R., Garavan, T. N., O'Brien, F., \& McDonnell, J. (2003). Predicting hotel managers' turnover cognitions. Journal of Managerial Psychology, 18(7), 649-679. doi: 10.1108/02683940310502377

Chalkiti, K., \& Sigala, M. (2010). Staff turnover in the Greek tourism industry. International journal of contemporary hospitality management, 22(3), 355-359. doi: 10.1108/09596111011035945

Chang, E. (1999). Career commitment as a complex moderator of organizational commitment and turnover intention. Human relations, 52(10), 1257-1278. doi: 10.1177/001872679905201002

Chang, H. T., Chi, N. W., \& Miao, M. C. (2007). Testing the relationship between three-component organizational/occupational commitment and organizational/occupational turnover intention using a non-recursive model. Journal of Vocational Behavior, 70(2), 352-368. doi: 10.1016/j.jvb.2006.10.001 
Cho, S., Johanson, M. M., \& Guchait, P. (2009). Employees intent to leave: A comparison of determinants of intent to leave versus intent to stay. International Journal of Hospitality Management, 28(3), 374381. doi: 10.1016/j.ijhm.2008.10.007

Choi, Y., \& Lee, D. (2014). Psychological capital, big five traits, and employee outcomes. Journal of Managerial Psychology, 29(2), 122-140. doi: 10.1108/JMP-o6-2012-0193

Choi, D., Oh, I.-S., \& Colbert, A. E. (2015). Understanding organizational commitment: A meta-analytic examination of the roles of the five-factor model of personality and culture. Journal of Applied Psychology, 100(5), 1542-1567. doi: 10.1037/aplooooo14

Cohen, J. (1988). Statistical power analysis for the behavioral sciences. Mahwah, NJ: Lawrence Erlbaum

Cohen, A. (1993). Organizational commitment and turnover: A meta-analysis. The Academy of Management Journal, 36(5), 1140-1157.

Costa, P. T., \& McCrae, R. R. (1992). Revised professional manual NEO personality inventory (NEO-PI-R) and NEO five-factor inventory (NEO-FFI). Odessa: Psychological Assessment Resources.

Cumming, G. (2012). Understanding the new statistics: Effect sizes, confidence intervals, and metaanalysis. New York, NY: Taylor \& Francis.

De Boeck, P., \& Jeon, M. (2018). Perceived crisis and reforms: Issues, explanations and remedies. Psychological Bulletin, 144(7), 757-777. doi: 10.1037/buloooo154

Dunn, W. S., Mount, M. K., Barrick, M. R., \& Ones, D. S. (1995). Relative importance of personality and general mental ability in managers' judgments of applicant qualifications. Journal of Applied Psychology, 8o(4), 500-509. doi: 10.1037/0021-9010.80.4.500

Durak, H. Y., \& Saritepeci, M. (2019). Occupational burnout and cyberloafing among teachers: Analysis of personality traits, individual and occupational status variables as predictors. The Social Science Journal, 56(1), 69-87. doi: 10.1016/j.soscij.2018.10.011

Durbarry, R., \& Sinclair, M. T. (2003). Market shares analysis: The case of French tourism demand. Annals of tourism research, 30(4), 927-941. doi: 10.1016/So16o-7383(03)00058-6

Dusek, G. A., Ruppel, C. P., Yurova, Y., \& Clarke, R. (2014). The role of employee service orientation in turnover in the US hotel industry. Journal of Organizational Culture, Communications and Conflict, 18(2), 87-104.

Erdheim, J., Wang, M., \& Zickar, M. J. (2006). Linking the Big Five personality constructs to organizational commitment. Personality and individual differences, 41(5), 959-970. doi: 10.1016/j.paid.2006.04.005

Faldetta, G., Fasone, V., \& Provenzano, C. (2013). Turnover in the hospitality industry: can reciprocity solve the problem? PASOS Revista de Turismo y Patrimonio Cultural, 11(4), 583-595. doi: 10.25145/J.PASOS.2013.11.052

Fang, R., Landis, B., Zhang, Z., Anderson, M. H., Shaw, J. D., \& Kilduff, M. (2015). Integrating personality and social networks: A meta-analysis of personality, network position, and work outcomes in organizations. Organization Science, 26(4), 1243-126o. doi: 10.1287/orsc.2015.0972

Farrukh, M., Ying, C. W., \& Mansori, S. (2017). Organizational commitment: an empirical analysis of personality traits. Journal of Work-Applied Management, 9(1), 18-34. doi: 10.4236/ojbm.2019.72031

Fornell, C., \& Larcker, D. F. (1981). Evaluating structural equation models with unobservable variables and measurement error. Journal of marketing research, 18(1), 39-50. doi: 10.2307/3151312

Freund, A., \& Carmeli, A. (2003). An empirical assessment: reconstructed model for five universal forms of work commitment. Journal of Managerial Psychology, 18(7), 708-725. doi: $10.1108 / 02683940310502403$

Funder, D. C., \& Ozer, D. J. (2019). Evaluating effect size in psychological research: Sense and nonsense. Advances in Methods and Practices in Psychological Science, 2(2), 156-168. doi: $10.1177 / 2515245919847202$ 
Gatling, A., Kang, H. J. A., \& Kim, J. S. (2016). The effects of authentic leadership and organizational commitment on turnover intention. Leadership E Organization Development Journal, 37(2), 181-199. doi: 10.1108/LODJ-05-2014-0090

Goldberg, L. R. (1999). A broad-bandwidth, public domain, personality inventory measuring the lowerlevel facets of several five-factor models. In I. Mervielde, I. Deary, F. De Fruyt, \& F. Ostendorf (Eds.), Personality psychology in Europe vol. 7 (pp. 7-28). Tilburg: Tilburg University Press.

Goldberg, L. R., Johnson, J. A., Eber, H. W., Hogan, R., Ashton, M. C., Cloninger, C. R., \& Gough, H. G. (2006). The international personality item pool and the future of public-domain personality measures. Journal of Research in personality, 40(1), 84-96. doi: 10.1016/j.jrp.2005.08.007

González-Santacruz, F., Sánchez-Cañizares, S., \& López-Guzmán, T. (2014) Organisational commitment: A key variable in the hotel sector of the province of Cordoba, Spain. European Journal of Tourism Research, 7, 109-126.

Griffeth, R. W., \& Hom, P.W. (1995). The employee turnover process. Research in Personnel and Human Resources Management, 13, 245-293.

Griffeth, R.W., Hom, P.W. \& Gaertner, S. (2000). A meta-analysis of antecedents and correlates of employee turnover: Update, moderator tests, and research implications for the next millennium. Journal of Management, 26(3), 463-488. doi: 10.1177/014920630002600305

Guay, R. P., Choi, D., Oh, I. S., Mitchell, M. S., Mount, M. K., \& Shin, K. H. (2016). Why people harm the organization and its members: Relationships among personality, organizational commitment, and workplace deviance. Human Performance, 29(1), 1-15. doi: 10.1080/08959285.2015.1120305

Hair Jr, J. F., Hult, G. T. M., Ringle, C., \& Sarstedt, M. (2016). A primer on partial least squares structural equation modeling (PLS-SEM). Thousand Oaks, CA: SAGE Publications, Inc.

Hair, J., Hollingsworth, C. L., Randolph, A. B., \& Chong, A. Y. L. (2017). An updated and expanded assessment of PLS-SEM in information systems research. Industrial Management $\mathcal{E}$ Data Systems, 117(3), 442-458. doi: 10.1108/IMDS-04-2016-0130

Hair Jr, J. F., Sarstedt, M., Hopkins, L., \& Kuppelwieser, V. G. (2014). Partial least squares structural equation modeling (PLS-SEM). European business review, 26(2), 106-121. doi:10.1108/EBR-10-2013-0128

Hair Jr, J. F., Sarstedt, M., Ringle, C. M., \& Gudergan, S. P. (2017). Advanced issues in partial least squares structural equation modeling. Thousand Oaks, CA: SAGE Publications, Inc.

Henseler, J., Ringle, C. M., \& Sarstedt, M. (2015). A new criterion for assessing discriminant validity in variance-based structural equation modeling. Journal of the Academy of Marketing Science, 43(1), 115135. doi: 10.1007/s11747-014-0403-8

Hinkin, T. R., \& Tracey, J. B. (2000). The cost of turnover: Putting a price on the learning curve. Cornell hotel and restaurant administration quarterly, 41(3), 14-21. doi: 10.1177/001088040004100313

Hoque, K. (1999). New approaches to HRM in the UK hotel industry. Human Resource Management Journal, 9(2), 64-76.

Hughes, D. J., \& Batey, M. (2017). Using personality questionnaires for selection. In H. W. Goldstein, E. D. Pulakos, J. Passmore, \& C. Semedo (Eds.), Wiley Blackwell handbooks in organizational psychology. The Wiley Blackwell handbook of the psychology of recruitment, selection and employee retention (p. 151-181). Hoboken, NJ: Wiley-Blackwell.

Ilies, R., Fulmer, I. S., Spitzmuller, M., \& Johnson, M. D. (2009). Personality and citizenship behavior: The mediating role of job satisfaction. Journal of Applied Psychology, 94, 945-959. http://dx.doi.org/10.1037/aoo13329

Indarti, S., Fernandes, A. A. R., \& Hakim, W. (2017). The effect of OCB in relationship between personality, organizational commitment and job satisfaction on performance. Journal of Management Development, 36(10), 1283-1293. doi: 10.1108/JMD-11-2016-0250

Iverson, R. D., \& Deery, M. (1997). Turnover culture in the hospitality industry. Human Resource Management Journal, 7(4), 71-82. doi: 10.1111/J.1748-8583.1997.TBoo29o.X 
Jang, J., \& George, R. T. (2012). Understanding the influence of polychronicity on job satisfaction and turnover intention: A study of non-supervisory hotel employees. International Journal of Hospitality Management, 31(2), 588-595. doi: 10.1016/j.ijhm.2011.08.004

Johnsrud, L. K., \& Rosser, V. J. (2002). Faculty members' morale and their intention to leave: A multilevel explanation. The Journal of Higher Education, 73(4), 518-542. doi: 10.1080/o0221546.2002.11777162

Joung, H. W., Goh, B. K., Huffman, L., Yuan, J. J., \& Surles, J. (2015). Investigating relationships between internal marketing practices and employee organizational commitment in the foodservice industry. International Journal of Contemporary Hospitality Management, 27(7), 1618-1640.

Judge, T. A., Higgins, C. A., Thoresen, C. J., \& Barrick, M. R. (1999). The big five personality traits, general mental ability, and career success across the life span. Personnel psychology, 52(3), 621-652. doi: $10.1177 / 1356766718757270$

INSETE. (2015). Specialization of Strategic Tourism Plan actions \& Strategic Study of Human Resources

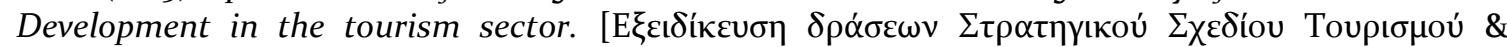

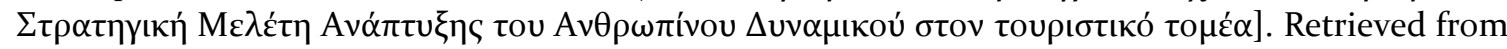
http://www.insete.gr/Portals/o/meletes-INSETE/10/2015_Strathgikh_Meleth_Anaptyxhs_AA.pdf

Kang, H. J. A., Busser, J., \& Choi, H. M. (2018). Service climate: How does it affect turnover intention? International Journal of Contemporary Hospitality Management, 30(1), 76-94. doi: 10.1108/IJCHM04-2016-0185

Karatepe, O. M., Arasli, H., \& Khan, A. (2007). The impact of self-efficacy on job outcomes of hotel employees: evidence from Northern Cyprus. International Journal of Hospitality $\mathcal{E}$ Tourism Administration, 8(4), 23-46.

Karsan, R. (2007). Calculating the cost of turnover. Employment Relations Today, 34(1), 33-36. doi: 10.1002/ert.20139

Kenny, D. A. (2016, September 15). Moderation. Retrieved from http://davidakenny.net/cm/moderation.htm

Kim, N. (2014). Employee turnover intention among newcomers in travel industry. International Journal of Tourism Research, 16(1), 56-64. doi: 10.1002/jtr.1898

Kim, H. J., Shin, K. H., \& Umbreit, W. T. (2007). Hotel job burnout: The role of personality characteristics. International Journal of Hospitality Management, 26(2), 421-434. doi: 10.1016/j.ijhm.2006.03.006

Kozako, I. N. A. M. F., Safin, S. Z., \& Rahim, A. R. A. (2013). The relationship of big five personality traits on counterproductive work behaviour among hotel employees: An exploratory study. Procedia Economics and Finance, 7, 181-187. doi: 10.14419/ijet.v7i3.30.18156

Kusluvan, S., Kusluvan, Z., Ilhan, I., \& Buyruk, L. (2010). The human dimension: A review of human resources management issues in the tourism and hospitality industry. Cornell Hospitality Quarterly, 51(2), 171-214. doi: 10.1177/1938965510362871

Langton N, \& Robbins S. (2007). Fundamentals of Organizational Behavior, ( $3^{\text {rd }}$ edition). Canada: Pearson Education Canada

Lee, K., Carswell, J.J., and Allen, N.J. (2000). A meta-analytic review of occupational commitment: Relations with person-and work-related variables. Journal of Applied Psychology, 85(5), 799-811. doi:10.1037/0021-9010.85.5.799

Lee, C. C., Huang, S. H., \& Zhao, C. Y. (2012). A study on factors affecting turnover intention of hotel empolyees. Asian Economic and Financial Review, 2(7), 866-875.

Lingard, H. (2003). The impact of individual and job characteristics on 'burnout' among civil engineers in Australia and the implications for employee turnover. Construction Management E Economics, 21(1), 69-80. doi: 10.1080/0144619032000065126

Matthews, L., Hair, J. O. E., \& Matthews, R. (2018). PLS-SEM: The Holy Grail For Advanced Analysis. Marketing Management Journal, 28(1), 1-13. 
McAulay, B. J., Zeitz, G., \& Blau, G. (2006). Testing a “push-pull” theory of work commitment among organizational professionals. The Social Science Journal, 43(4), 571-596.

McGunnigle, P. J., \& Jameson, S. M. (2000). HRM in UK hotels: a focus on commitment. Employee Relations, 22(4), 403-422. doi: 10.1108/01425450010340380

Mercer, M. W. (1988). Turnover-reducing the costs. Personnel, 65(12), 36-40.

Meyer, J. P. (2009). Commitment in a changing world of work. In H. J. Klein, T. E. Becker, and J. P. Meyer (Eds.), Commitment in Organizations: Accumulated Wisdom and New Directions (pp. 37-68). New York: Routledge/Taylor \& Francis.

Meyer, J. P., \& Allen, N. J. (1991). A three-component conceptualization of organizational commitment. Human resource management review, 1(1), 61-89.

Meyer, J. P., \& Allen, N. J. (1997). Commitment in the workplace: Theory, research, and application. Thousand Oaks, CA: Sage.

Meyer, J. P., Allen, N. J., \& Smith, C. A. (1993). Commitment to organizations and occupations: Extension and test of a three-component conceptualization. Journal of applied psychology, 78(4), 538. doi: 10.1037/0021-9010.78.4.538

Meyer, J. P., Stanley, D. J., Herscovitch, L., \& Topolnytsky, L. (2002). Affective, continuance, and normative commitment to the organization: A meta-analysis of antecedents, correlates, and consequences. Journal of vocational behavior, 61(1), 20-52. doi: 10.1006/jvbe.2001.1842

Meyer, J.P., Stanley, L.J., \& Vandenberg, R.J. (2013). A person-centered approach to the study of commitment. Human Resource Management Review, 23(2), 190-202. doi: 10.1016/j.hrmr.2012.07.007

Michel, J. S., Clark, M. A., \& Jaramillo, D. (2011). The role of the Five Factor Model of personality in the perceptions of negative and positive forms of work-nonwork spillover: A meta-analytic review. Journal of Vocational Behavior, 79(1), 191-203. doi: 10.1016/j.jvb.2010.12.010

Morrow, P. C. (1983). Concept redundancy in organizational research: The case of work commitment. Academy of management Review, 8(3), 486-500. doi: 10.2307/257837

Mullins, L. J. \& Dossor, P. (2013). Hospitality management and organisational behaviour (5 ${ }^{\text {th }}$ ed). Essex, UK: Pearson Education Limited.

Nadiri, H., \& Tanova, C. (2010). An investigation of the role of justice in turnover intentions, job satisfaction, and organizational citizenship behavior in hospitality industry. International journal of hospitality management, 29(1), 33-41. doi: 10.1016/j.ijhm.2009.05.001

Park, J., \& Min, H. K. (2020). Turnover intention in the hospitality industry: A meta-analysis. International Journal of Hospitality Management, 90, 102599. doi: 10.1016/j.ijhm.2020.102599

Riley, M. (2018). Managing People in the Hospitality Industry. New York, NY: Routledge.

Ringle, C.M., Wende, S. and Becker, J.M. (2015) SmartPLS 3. SmartPLS GmbH: Boenningstedt. Retrieved from http://www.smartpls.com

Riva, G., Teruzzi, T., \& Anolli, L. (2003). The use of the internet in psychological research: Comparison of online and offline questionnaires. CyberPsychology $\mathcal{E}$ Behavior, 6(1), 73-80. doi: 10.1089/109493103321167983

Roscoe, J.T. (1975) Fundamental Research Statistics for the Behavioral Science, International Series in Decision Process, 2nd Edition. New York, NY: Holt, Rinehart and Winston, Inc.

Rothmann, S., \& Coetzer, E. P. (2003). The big five personality dimensions and job performance. $S A$ Journal of Industrial Psychology, 29(1), 68-74. doi: 10.4102/sajip.v29i1.88

Rubenstein, A. L., Zhang, Y., Ma, K., Morrison, H. M., \& Jorgensen, D. F. (2019). Trait expression through perceived job characteristics: A meta-analytic path model linking personality and job attitudes. Journal of Vocational Behavior, 112, 141-157. doi: 10.1016/j.jvb.2019.02.002

Rust, R. T., Stewart, G. L., Miller, H., \& Pielack, D. (1996). The satisfaction and retention of frontline employees. International Journal of Service Industry Management, 7(5), 62-80. doi: 10.1108/09564239610149966 
Salgado, J. F. (2002). The Big Five personality dimensions and counterproductive behaviors. International journal of selection and assessment, 10(1-2), 117-125. doi: 10.1111/1468-2389.00198

Scarr, S. (1996). How people make their own environments: Implications for parents and policy makers. Psychology, Public Policy, and Law, 2(2), 204-228. doi:10.1037/1076-8971.2.2.204.

Schonlau, M., Ronald Jr, D., \& Elliott, M. N. (2002). Conducting research surveys via e-mail and the web. Sanda Monica, CA: Rand Corporation.

Sekaran, U., \& Bougie, R. (2016). Research methods for business: A skill building approach (7 ${ }^{\text {th }}$ edition). John Wiley \& Sons.

Shoda, Y., Mischel, W., \& Wright, J. C. (1993). The role of situational demands and cognitive competencies in behavior organization and personality coherence. Journal of personality and social psychology, 65(5), 1023-1035. doi: 10.1037//o022-3514.65.5.1023

Siddiqui, K. (2013). Heuristics for sample size determination in multivariate statistical techniques. World Applied Sciences Journal, 27(2), 285-287. doi: 10.5829/idosi.wasj.2013.27.02.889

Siders, M. A., George, G., \& Dharwadkar, R. (2001). The relationship of internal and external commitment foci to objective job performance measures. Academy of Management Journal, 44(3), 570-579. doi: 10.2307/3069371

Sigala, M. (2006, October). Performance impact offlexible working in hotels. Paper presented at the 24rd EuroCHRIE International Congress "In search of Excellence for tomorrow's tourism, travel and hospitality", Thessaloniki, Greece.

Silva, P. (2006). Effects of disposition on hospitality employee job satisfaction and commitment. International Journal of Contemporary Hospitality Management, 18(4), 317-328. doi: $10.1108 / 09596110610665320$

Skarlicki, D.P., Folger, R., Tesluk, P., 1999. Personality as a moderator in the relationship between fairness and retaliation. The Academy of Management Journal 42(1), 100-108. doi: 10.2307/256877

Spagnoli, P., \& Caetano, A. (2012). Personality and organisational commitment: The mediating role of job satisfaction during socialization. Career Development International, 17(3), 255-275. doi: $10.1108 / 13620431211241081$

Spector, P. E. (2012). Self-reports for employee selection. In N. Schmitt (Ed.), The Oxford handbook of personnel assessment and selection (pp. 443-461). New York: Oxford University Press. doi: 10.1093/oxfordhb/9780199732579.001.0001

Tasci, A. D., \& Knutson, B. J. (2003). Online research modes: Waiting for leisure, hospitality and tourism researchers. Journal of Hospitality \& Leisure Marketing, 10(3-4), 57-83. doi: 10.1300/J150v10no3_04

Tesone, D. V. (Ed.). (2008). Handbook of hospitality human resources management. New York, NY: Routledge.

Tett, R.P. \& Meyer, J.P. (1993). Job satisfaction, organizational commitment, turnover intention, and turnover: Path analyses based on meta-analytic findings. Personnel Psychology, 46(2), 259-293. doi: 10.1111/j.1744-6570.1993.tboo874.X

Tews, M. J., Stafford, K., \& Tracey, J. B. (2011). What matters most? The perceived importance of ability and personality for hiring decisions. Cornell Hospitality Quarterly, 52(2), 94-101. doi: 10.1111/j.17446570.1993.tboo874.x

Tews, M. J., Stafford, K., \& Zhu, J. (2009). Beauty revisited: The impact of attractiveness, ability, and personality in the assessment of employment suitability. International Journal of Selection and Assessment, 17(1), 92-100. doi: 10.1111/j.1468-2389.2009.00454.x

Timmerman, T. A. (2006). Predicting turnover with broad and narrow personality traits. International Journal of Selection and Assessment, 14(4), 392-399.

Tsoumbris, P., \& Xenikou, A. (2010). Commitment profiles: The configural effect of the forms and foci of commitment on work outcomes. Journal of Vocational Behavior, 77(3), 401-411. doi: 10.1016/j.jvb.2010.07.006 
Tziner, A., Waismal-Manor, R., Vardi, N., \& Brodman, A. (20o8). The personality dispositional approach to job satisfaction and organizational commitment. Psychological reports, 103(2), 435-442.

US Department of Labor, Bureau of Labor Statistics. (2015). Job Openings and Labor Turnover Survey News Release. Retrieved from https://www.bls.gov/news.release/archives/jolts_02092016.htm

Vance, R. J., Jaros, S., Becker, T. E., \& McKay, A. S. (2020). Alternative Measures of Employee Commitment: Assessment of Predictive Validity for Performance and Turnover. Human Performance, 33(2-3), 164-190. doi:10.1080/08959285.2020.1759071

Vandenberg, R. J., \& Scarpello, V. (1994). A longitudinal assessment of the determinant relationship between employee commitments to the occupation and the organization. Journal of Organizational Behavior, 15(6), 535-547. doi: 10.1002/job.4030150605

Vandenberghe, C., Bentein, K., \& Panaccio, A. (2014). Affective Commitment to Organizations and Supervisors and Turnover: A Role Theory Perspective. Journal of Management, 43(7), 2090-2117. doi: 10.1177/0149206314559779

Wanberg, C. R., Kanfer, R., \& Banas, J. T. (2000). Predictors and outcomes of networking intensity among unemployed job seekers. Journal of Applied Psychology, 85(4), 491. Doi: 10.1037/oo219010.85.4.491

Watson, D., \& Clark, L. A. (1997). Extraversion and its positive emotional core. In S. R. Briggs, W. H. Jones, \& R. Hogan (Eds.), Handbook of personality psychology (pp. 767-793). New York, NY: Academic Press.

World Medical Association. (2001). World medical association declaration of Helsinki. Ethical principles for medical research involving human subjects. Bulletin of the World Health Organization, 79(4), 373.

WTTC (2020). Economic Impact Reports, Greece 2020 Annual Research. London: World Travel \& Tourism Council. Retrieved from https://wttc.org/Research/Economic-Impact

Wu, C., \& Mursid A., (2019). The relationship between personality, customer participation, customer value and customer satisfaction in tourism service. European Journal of Tourism Research, 23, 156171. Retrieved from https://ejtr.vumk.eu/index.php/about/article/view/395

Yang, J. T. (2008). Effect of newcomer socialisation on organisational commitment, job satisfaction, and turnover intention in the hotel industry. The Service Industries Journal, 28(4), 429-443. doi: $10.1080 / 02642060801917430$

Yang, J. T. (2010). Antecedents and consequences of job satisfaction in the hotel industry. International Journal of Hospitality Management, 29(4), 609-619. doi:10.1080/02642060801917430

Yousaf, A., Sanders, K., \& Abbas, Q. (2015). Organizational/occupational commitment and organizational/occupational turnover intentions. Personnel Review, 44(4), 470-491. doi: 10.1108/PR12-2012-0203

Yousaf, A., Sanders, K., \& Shipton, H. (2013). Proactive and politically skilled professionals: What is the relationship with affective occupational commitment? Asia pacific journal of management, $30(1), 211-$ 230. doi: 10.1007/s10490-011-9253-9

Ypofanti, M., Zisi, V., Zourbanos, N., Mouchtouri, B., Tzanne, P., Theodorakis, Y., \& Lyrakos, G. (2015). Psychometric properties of the International Personality Item Pool Big-Five personality questionnaire for the Greek population. Health Psychology Research, 3(2), 2206. doi: 10.4081/hpr.2015.2206

Zettler, I., Friedrich, N., \& Hilbig, B. E. (2011). Dissecting work commitment: The role of Machiavellianism. Career Development International, 16(1), 20 - 35. doi: 10.1108/13620431111107793

Zhao, H., Seibert, S. E., \& Lumpkin, G. T. (2010). The relationship of personality to entrepreneurial intentions and performance: A meta-analytic review. Journal of management, 36(2), 381-404. doi: 10.1177/0149206309335187 
Zimmerman, R. D. (2008). Understanding the impact of personality traits on individuals' turnover decisions: a meta-analytic path model. Personnel psychology, 61(2), 309-348. Doi: 10.1111/j.17446570.2008.00115. $\mathrm{X}$

Zopiatis, A., Constanti, P., \& Theocharous, A. L. (2014). Job involvement, commitment, satisfaction and turnover: Evidence from hotel employees in Cyprus. Tourism Management, 41, 129-140. doi: 10.1016/j.tourman.2013.09.013

Received: 23/03/2021

Accepted: 29/04/2021

Coordinating editor: Giacomo Del Chiappa 